\title{
ResearchOnline@JCU
}

This is the Accepted Version of a paper published in the journal of Tropical Psychology:

Lee, Janice Niann Tsyr, Foo, Koong, Adams, Austin, Morgan, Robert, and Frewen, Amie (2015) Strengths of character, orientations to happiness, life satisfaction and purpose in Singapore. Journal of Tropical Psychology, 5.

$$
\text { pp. 1-21. }
$$

http://dx.doi.org/10.1017/jtp.2015.2 


\title{
Strengths of Character, Orientations to Happiness, \\ Life Satisfaction and Purpose in Singapore
}

\author{
Niann Tsyr Janice Lee \\ The Center for Psychology, Singapore \\ Koong Hean Foo and Austin Adams \\ James Cook University \\ Robert Morgan \\ Morgan Foundation Publishers, Albuquerque, New Mexico, USA \\ Amie Frewen \\ James Cook University
}

Author Note

This research was approved by the Human Research Ethics Committee and sponsored by James Cook University.

Address for Correspondence: Janice Lee Niann Tsyr, The Center for Psychology491B, River Valley Road \#04-01 Valley Point, Singapore 248373. Email: jlee@ center4psy.com 


\begin{abstract}
Positive psychology has identified 6 virtues comprising 24 character strengths of humans. This study examines the relationships among these character strengths, including Happiness, Life Purpose and Life Satisfaction as valued by Singapore Chinese, Malays, Indians, and Other Asians and Caucasians. A sample of Singapore adults $(N=304)$ completed an online survey in English comprising four measures, the Values in Action Inventory of Strengths, the Orientations to Happiness Scale, the Satisfaction with Life Scale, and the Life Engagement Test. Results show that Zest, Hope, Curiosity, Capacity to Love and Gratitude are the top five character strengths of the sampled Singaporeans. Happiness orientation through pursuing a Life of Meaning is preferred by all four ethnic groups. Ethnic differences are found for character strengths of Kindness, Humour, Gratitude, and Religiousness and Spirituality. Life of Meaning and Life of Engagement, Happiness orientations, and character strengths of Curiosity and Perseverance are direct predictors of Life Purpose. In turn, Life Purpose and character strengths of Capacity to Love and Gratitude are found to be direct predictors of Life Satisfaction. Despite its other limitations, this study lays the groundwork for future studies using more robust sampling strategies and greater participation from the major ethnic groups in Singapore.
\end{abstract}

Keywords: Strengths of Character, Happiness, Life Satisfaction, Singapore, Ethnic groups

[Note: This article presents the gist of the doctoral study of the first author. Readers interested in details on the study may wish to contact the first author at email: jlee@center4psy.com]. 


\section{Strengths of Character, Orientations to Happiness, Life Satisfaction and Purpose in Singapore}

The study of positive psychology, of psychological well-being particularly, involves examining factors of happiness, positive character traits and the perceived sense of life purpose and satisfaction (Seligman \& Peterson, 2003). The aim of positive psychology is to concentrate on building a science of positive human qualities that improves the quality of life, and prevents the development of illnesses when life becomes difficult and meaningless (Seligman \& Csikszentmihalyi, 2000). In other words, the main goal of positive psychology is to increase human flourishing through the emphasis on well-being. A "good life" means a life that is well-lived and fulfilling. It is to be pleasant, engaging, meaningful, achieving and must include a connectedness with others through positive relationships (Seligman, 2011).

Along these lines, the purpose of the present study is twofold: (1) to examine the relationships among character strengths, happiness, life purpose and life satisfaction of Singaporeans; and (2) the identification of robust character strengths valued by the ethnic groups of Singapore (the Chinese, Malays, Indians and Other Asians and Caucasians) in their pursuit of happiness, life purpose and life satisfaction. An enhanced understanding of the positive and emotionally fulfilling aspects of well-being among these ethnic groups in Singapore can contribute to legislative, institutional and community efforts for community harmony, longevity and the better utilization of human resources in this small, global city.

According to the 2010 Singapore Census of Population, published by the Department of Statistics, Singapore, in January 2011, the Singapore resident population in 2010 comprised $74.1 \%$ Chinese, $13.4 \%$ Malays, 9.2\% Indians and 3.3\% Others. The Singapore government has formulated a number of legislative initiatives to enhance relationships among ethnic groups (e.g., the Presidential Council for Minority Rights in 1973; the Maintenance of Religious Harmony Act in 1990; and the Declaration on Religious Harmony in 2003) and implemented programmes and policies to foster social cohesion (e.g., public housing ethnic quotas to create opportunities to interact with fellow Singaporeans from different ethnic and religious groups; and the formation of Inter-religious Harmony Circles in schools and workplaces; Teng, 2011). Against the diverse background of multi-lingual, multi-cultural and multi-religious practices among the ethnic groups, the Singapore government has emphasized the tolerance of differences for harmonious living and unity for its people. The national pledge; "We, the citizens of Singapore, pledge ourselves as one united people, regardless of race, language or religion, to build a democratic society based on justice and equality so as to achieve happiness, prosperity and progress for our nation" embodies the national values that 
Running Head: CHARACTER STRENGTHS IN SINGAPORE

the Singapore government aims to cultivate in the people of Singapore. The Singapore government is resolved to provide a safe and secured living environment for each individual so as to have a viable economy which has been dependent on tourists and foreign investments (Teng, 2011). The present study provides data to assist in this process.

\section{Wellbeing}

Studies on a well-lived and fulfilling life have focused on subjective well-being, life satisfaction and happiness (Compton, 2005). Subjective wellbeing is defined as an individual's emotional and cognitive evaluation of their lives that includes everyday terms such as happiness, fulfilment, peace, and life satisfaction. It is also related to how well individuals think of themselves as achieving the things they value (Diener, Oishi, \& Lucas, 2003). Age, gender, education, money, race and climate tend not to be significant predictors of subjective well-being, though their impact is through the influence of social class, income and education (Compton, 2005). People who are materialistic and value money more are less satisfied with life and less able to gain satisfaction from having money (Kasser \& Ryan, 1993; Sirgy, 1998). For Singaporeans, non-economic wellbeing is crucial to the overall sense of happiness and achievement in life (Tambyah, Tan, \& Kau, 2010). These researchers advocate the continual monitoring of quality of life among Singaporeans, stressing that it is important to have the government, the private sector, non-profitable organisations and civil society groups collaborate with one another to ensure that Singaporeans' quality of life is continually enhanced.

People of different cultures pursue well-being in different ways (Compton, 2005). For example, Asian cultures are inclined to value social harmony over individual achievement (Suh \& Oishi, 2002). Chinese define a good life as one involving a happy and healthy family, community involvement, children who are well-adjusted, and involving positive and lasting friendships (Tafarodi et al., 2011). Japanese also value close and lasting friendships; to them, having hobbies and leisure activities are important. Indians value good family relations. Whereas Canadians would include the experience of world travel in their definition of a good life; they are relatively less concerned with social status.

A fine example on the application of subjective wellbeing for institution and society is seen in the change occurred in the Singapore Prison Service (Helliwell, 2011). Inmates and prison staff gather, work, play and live resulting in improved wellbeing. Among the outcomes were: Recidivism dropped from $44 \%$ for the cohort released in 1998 to $23.7 \%$ for the cohort released in 2004; improved staff morale and better social connections between the prisons and the rest of Singapore society; and prisons were converted into schools for life. Five key 
Running Head: CHARACTER STRENGTHS IN SINGAPORE

aspects of wellbeing were observed: improving social context, valuing benevolence, building trust, emphasizing positive outcomes, and instituting bottom-up initiatives and engagement approaches with shared visions, goals and purposes. The Singapore Mental Health Study by Vaingankar et al. (2011), comprising 2,565 participants from Chinese, Malay and Indian ethnic groups, aged 21 to 65 years old, identified six culturally appropriate and important domains of mental health for Singapore: General coping, Emotional support, Spirituality, Interpersonal skills, Personal growth and autonomy, and Global affect.

\section{Life Satisfaction and Happiness}

Life satisfaction could be measured based on cognitive judgements of how one views life circumstances with one's personal standards that one imposes internally for oneselfone that involves a global assessment of life rather than only a narrow assessment of one life domain (Diener, Emmons, Larsen, \& Griffin, 1985). The search for further meaning and purpose in life is positively associated with greater life satisfaction, more happiness and less depression for those who have already established some meaning in their lives (Park, Park, \& Peterson, 2010). People want to live life more fully by having personal meaning and purpose in life. People want to have meaningful and fulfilling lives, to instill and nurture what is best within them, and to enhance their experiences of love, work, and play (Seligman, 2002).

People all over the world want to be happy and think that happiness is crucial (Diener $\&$ Scollon, 2003). Happiness is closely associated with optimal functioning in humans in that it is a core expressed indication of optimal functioning, since we feel good when overall life is well (Veenhoven, 2011). People in individualist cultures tended to choose high-arousal type of positive emotions like enthusiasm and excitement whereas people from collectivist cultures preferred positive emotions of low-arousal like calmness and tranquillity (Trach \& Lyubomirsky, 2006). East Asians value achievement and mastery more than happiness although people in Latin American societies value happiness to a greater extent.

In a study (Park, Peterson, \& Ruch, 2009) in which happiness is proposed as an indicator of psychological well-being at the level of nations, 24,836 adults from 27 nations completed online surveys in English to measure happiness-seeking orientations through pleasure, engagement and meaning, and life satisfaction. Three cluster groups resulted. Cluster One consisted of five nations which scored relatively low on all three orientations to pleasure, engagement and meaning. Cluster Two comprised 13 nations which had higher scores on pleasure and engagement orientations. Cluster Three of nine nations, in which Singapore was included but with only 31 participants, had higher scores on engagement and meaning orientations. All three happiness-seeking orientations positively correlated with life 
satisfaction in the 27 nations. Pleasure orientation was found to be a less robust predictor of life satisfaction compared to orientations of engagement and meaning. A major limitation in the study was the non-representativeness of the samples; twenty of the 27 nation samples were small (20 to 99 participants) and from different cultural backgrounds.

In another study (Seligman, Steen, Park, \& Peterson, 2005), five happiness interventions were placed on the Internet to recruit participants, deliver interventions and collect data. One intervention focused on building gratitude, two interventions were directed towards increasing awareness of what is positive in oneself, and another two emphasized identifying personal strengths. A placebo control exercise required participants to write about early memories every night for a week. Participants received a randomly assigned exercise to do for a week and were instructed to return to the website to complete follow-up questionnaires after their assigned exercise was completed. Those who were assigned an intervention of using character strengths were asked to take the inventory of character strengths online at www.authentichappiness.org including obtaining individualised feedback about their top five signature character strengths. These participants were then requested to use one of their top strengths in a new and different way daily for a week. Individuals who used their signature character strengths in a new way daily for a week, and also those who, in another intervention, wrote about three good things that occurred daily and why these happened, were found to have increased positive emotions of being happy and decreased lowmood symptoms for six months. Such research outcomes support the effectiveness of psychological-happiness interventions on increasing personal happiness for the individual. Research has also suggested that individuals recovering from serious illness and psychological disorders express increased life satisfaction with higher levels of endorsement for character strengths such as Bravery, Love of Learning, Appreciation of Beauty, and Excellence, Humour and Kindness, when compared to those who have not recovered and who have reported low levels of life satisfaction (Peterson, Park, \& Seligman, 2006).

\section{Character Strengths and Virtues}

Humans can gain good life through the cultivation, nurturing and exercising of good character, where good character is demonstrated through the individual's positive traits (Seligman \& Csikszentmihalyi, 2000). Living a good life means using one's positive traits to gain gratifications in the main spheres of one's life; gratifications can only be obtained by developing personal strengths and virtues (Seligman, 2002). Virtues are core valued characteristics that religious thinkers and moral philosophers term as qualities desired of people due to intrinsic worth inherent in these qualities. Character strengths are the 
Running Head: CHARACTER STRENGTHS IN SINGAPORE

psychological components that make up these virtues (Park \& Peterson, 2009). Character strengths are defined as positive individual traits or morally-valued personality aspects that are expressed in thoughts, feelings and behaviours. Peterson and Seligman (2004) have identified core positive traits commonly valued across world cultures and throughout human history. Results from the research of Proctor, Maltby, and Linley (2010) suggest crucial links between generic strengths, such as self-esteem and self-efficacy, and specific character strengths as conceptualized by the 24 character strengths classification system known as the Values-In- Action-Inventory of Strengths (VIA-IS) developed by Peterson and Seligman (2004).

The 24 character strengths are categorized under six virtues by Peterson and Seligman (2004). These virtues are wisdom and knowledge, courage, humanity, justice, temperance, and transcendence. For details on the character strengths, please refer to Peterson and Seligman (2004). Park, Peterson, and Seligman (2006) investigated the relative prevalence of the 24 character strengths using data of 117,676 adults from 54 nations, including 172 Singapore respondents. The most commonly endorsed strengths in 54 countries and 50 U.S. states were Kindness, Fairness, Honesty, Gratitude and Judgment and Open-mindedness, whereas lesser strengths were Prudence, Modesty and Self-regulation. High correlations, ranging in the $.80 \mathrm{~s}$, were found between nations in their support of specific character strengths, regardless of cultural, ethnic and religious differences. Generalization of the findings is limited due to the small sample sizes and the over-representation of well-educated respondents in the 53 non-US nations compared to the US sample.

\section{Purpose and Meaning in Life}

Marsh et al. (2003) define having purpose and meaning in life as having a sense of clear direction in life, a sense of attaining life goals, a belief that daily living activities are meaningful and worthwhile, and a sense of living that is coherent and meaningful coupled with zest and excitement about life. Meaning and purpose in life is crucial for well-being, though it may be defined differently and the routes to it may be different (Steger et al., 2006). The sense of meaning and purpose is something to be learnt, discovered or created, and that this process can be difficult (Baumeister $\&$ Voh, 2002). If people can see their pain and suffering as having value and meaning, they can better engage with life and derive meaning from this engagement (Steger et al., 2006; Park, Park, \& Peterson, 2010). The search for meaning and purpose in life is worthwhile and can be satisfying (Park et al., 2010). In addition, it is much better to engage in life through engaging in meaningful work or activities, and then to derive from this engagement the meaning and purpose of life. 
Research has supported the link between meaning in life and well-being as a route to happiness (Park et al., 2009). Having valued goals in life gives purpose for living, the evidence for which is provided as an individual stays behaviourally engaged in life (Scheier et al., 2006). Any behaviour is a symbol of a valued goal in and of itself and secondly is a means of achieving an intangible, higher-order valued goal. An example of behaviour representing the valued goal in and of itself is eating for the sake of performing the behaviour of eating, while the behaviour of eating in order to stay alive and healthy represents behaviour with a higher-order goal. Humans must find meaningful activities to be engaged with or else life would seem without purpose and feelings of emptiness would ensue, with such feelings having crucial negative effects on overall well-being (Wrosch, Scheier, Miller, Schulz, and Carver, 2003).

\section{Predictors of Life Satisfaction: Happiness, Character Strengths and Life Purpose}

The results of the two studies (Peterson et al., 2005, 2007) show that all three happiness routes (namely, meaning, pleasure and engagement) on the Orientations to Happiness Scale are associated with life satisfaction as measured by the Satisfaction with Life Scale, and that among all three orientations, the orientation to pleasure has the weakest association with life satisfaction. In a similar study by Park et al. (2009) across 27 countries, nations which scored low on all three happiness orientations also scored lower life satisfaction than nations with high preference for pleasure and engagement, and nations with high preference for engagement and meaning. These studies focused on the relationships linking happiness, character strengths and life satisfaction but did not study the impact of life purpose and meaning on these variables. Although Park et al. (2009) make reference to past research investigating the relationships of happiness and life satisfaction with having meaning and purpose of life, no study has yet investigated the links between character strengths and life purpose.

\section{Current study}

Based on previous research discussed, the present study replicates in Singapore the study of Peterson et al. (2007) with an added measure assessing life purpose, conceptualized and defined by Scheier et al. (2006) as the extent to which an individual engages in activities considered personally valuable and significant. The present study is likely to have practical and potentially useful outcomes in enhancing mutual understanding among the different ethnic groups in Singapore or in general, people in Singapore for the promotion and maintenance of social harmony. The present study applies to the citizens and permanent residents of Singapore comprising Malays, Chinese, Indians and Other Asians and 
Caucasians but will include Eurasians and people from other minority ethnicity groups. Besides contributing to building and sustaining the field of positive psychology, this current research aims to examine the relationships of character strengths, approaches to happiness, life purpose and life satisfaction, and whether particular character strengths are related to various approaches to happiness, life purpose and life satisfaction among the ethnic groups of Singapore.

The hypotheses are as follows: H1: That the three happiness orientations (Life of Pleasure, Life of Engagement and Life of Meaning) will be positively correlated with life satisfaction. H2: That life purpose will correlate with the three happiness orientations. H3: That life purpose will correlate with life satisfaction. H4: That most of the 24 character strengths will be correlated with each of the happiness orientations. H5: That the top five strengths strongly correlated with life satisfaction will be Zest, Hope, Love, Curiosity and either Gratitude or Perseverance. H6: That the top character strengths correlating with life purpose will also correlate with life satisfaction. H7: That particular character strengths will be most associated with each happiness orientation. H8: That Life Purpose, all three happiness orientations (Life of Pleasure, Life of Engagement and Life of Meaning), and character strengths of Hope, Gratitude, Capacity to Love and Zest (with no mediating paths involving the happiness orientations) will contribute to predicting Life Satisfaction.

\section{Method}

\section{Participants}

Of the 304 participants, $229(75.3 \%)$ described themselves as being of Chinese descent, 24 (7.9\%) of Malay descent, 30 (9.9\%) of Indian descent and 21 (6.9\%) of Eurasian, mixed and other ethnic group descent (such as Arabs, Filipinos and Caucasians). These ethnic sampling sizes are quite representative of the Singapore resident population. Table 1 provides demographic information on the study sample: 107 female (68.1\%) and 97 male (31.9\%); 174 participants were single, 121 married, 8 divorced and 1 widowed; participants aged between 30 and 39 years $(31.6 \%)$ formed the largest group; all participants had completed their secondary school education (39.1\% were graduates; $24 \%$ post graduates).

\section{Design}

An online questionnaire-based, cross-sectional, within-group research design was used. The variables examined were the endorsed routes to happiness in life, satisfaction with life, purpose in life and the positive personal qualities that individuals identified as their most prominent character strengths. 
Table 1

Demographic Information based on Ethnicity $(N=304)$

\begin{tabular}{|c|c|c|c|c|c|}
\hline & & $\begin{array}{l}\text { Malays } \\
(n=24)\end{array}$ & $\begin{array}{l}\text { Indians } \\
(n=30)\end{array}$ & $\begin{array}{l}\text { Chinese } \\
(n=229)\end{array}$ & $\begin{array}{c}\text { Other Asians } \\
\text { and Caucasians } \\
(n=21)\end{array}$ \\
\hline \multirow[t]{2}{*}{ Gender } & Male & 8 & 7 & 77 & 5 \\
\hline & Female & 16 & 23 & 152 & 16 \\
\hline \multirow[t]{2}{*}{ Nationality } & Singapore Citizen & 23 & 28 & 207 & 15 \\
\hline & Singapore Permanent Resident & 1 & 2 & 22 & 6 \\
\hline \multirow[t]{4}{*}{ Marital Status } & Single & 9 & 18 & 134 & 13 \\
\hline & Married & 13 & 10 & 90 & 8 \\
\hline & Divorced & 2 & 2 & 4 & 0 \\
\hline & Widowed & 0 & 0 & 1 & 0 \\
\hline \multirow[t]{6}{*}{ Education } & Secondary & 2 & 2 & 23 & 3 \\
\hline & Institute of Technical Education & 4 & 1 & 4 & 1 \\
\hline & Post Secondary & 0 & 7 & 17 & 2 \\
\hline & Polytechnic & 7 & 3 & 34 & 2 \\
\hline & Graduate & 5 & 9 & 96 & 9 \\
\hline & Post-Graduate & 6 & 8 & 55 & 4 \\
\hline \multirow[t]{6}{*}{ Age in years } & $18-21$ & 2 & 4 & 19 & 2 \\
\hline & $22-29$ & 7 & 12 & 54 & 10 \\
\hline & $30-39$ & 10 & 7 & 73 & 6 \\
\hline & $40-49$ & 4 & 7 & 52 & 1 \\
\hline & $50-59$ & 1 & 0 & 27 & 1 \\
\hline & 60 and above & 0 & 0 & 4 & 1 \\
\hline \multirow[t]{14}{*}{ Occupation } & Arts \& Media & 1 & 1 & 5 & 0 \\
\hline & Business & 0 & 0 & 12 & 1 \\
\hline & Education & 1 & 3 & 13 & 1 \\
\hline & Engineering & 0 & 0 & 8 & 1 \\
\hline & Healthcare \& Medicine & 5 & 3 & 32 & 4 \\
\hline & Homemaker & 0 & 1 & 12 & 1 \\
\hline & Management & 2 & 2 & 8 & 0 \\
\hline & Office \& Administration & 1 & 3 & 30 & 0 \\
\hline & Others (incl. retired \& unemployed) & 5 & 3 & 30 & 4 \\
\hline & Sales & 0 & 0 & 7 & 2 \\
\hline & Science & 0 & 0 & 3 & 0 \\
\hline & Service & 1 & 0 & 4 & 0 \\
\hline & Social Service & 4 & 1 & 25 & 0 \\
\hline & Student & 4 & 13 & 40 & 7 \\
\hline
\end{tabular}

\section{Measures}

An online survey questionnaire was created using free survey design software available on the Internet. The questionnaire (see Appendix for adjusted copy of the questionnaire for publication) consisted of socio-demographic information (participant's name, email contact, age, occupation, highest education level, gender, nationality/residential status, ethnic group and marital status), and four measures-Orientations to Happiness Scale, the Satisfaction with Life Scale, the Life Engagement Test, and the Values in Action Inventory of Strengths. The first three measures were transcribed from their sources respectively, whereas the last measure was written down for use from the website; http://www.authentichappiness.com. The measures were all available without charge.

Orientations to Happiness Scale (OHS). The OHS (Peterson et al., 2005) consists of 18 items for measuring the degree to which an individual endorses each of the three 
happiness orientations (subscales) - a life of pleasure, a life of engagement or a life of meaning. Each subscale consists of six items. Sample items include: "My life serves a higher purpose" (life of meaning); "Life is too short to postpone the pleasures it can provide" (life of pleasure); and "I seek out situations that challenge my skills and abilities" (life of engagement). Responses to each item are made on a 5-point scale of 1 (not like me at all) to 5 (very much like me). Responses to items of each subscale are added to obtain scores reflecting the degree of endorsement of the three orientations to achieving happiness in life for the individual participant. Reliabilities of subscales are high (pleasure $\alpha \mathrm{s}=.84$, engagement $\alpha$ s $=.77$, meaning $\alpha \mathrm{s}=.88$; Peterson et al., 2005). Each subscale is individually correlated to better life satisfaction though the orientation to pleasure has the weakest links to well-being when compared to the orientations to engagement and pleasure. Cronbach alphas are high for the three types of endorsement as routes to happiness (.80 for pleasure, .70 for engagement, and .83 for meaning; Park et al., 2009).

Satisfaction with Life Scale (SWLS). The SWLS (Diener et al., 1985) comprises 5 items for measuring an individual's evaluation of satisfaction with his or her life in general. The SWLS measures affective well-being and life satisfaction, and assesses global life satisfaction as a cognitive-judgemental process. Scores are reported as being in one of six ranges, with the highest score 30 to 35 being described as being "highly satisfied" to the lowest score 5 to 9 being described as being "extremely dissatisfied". The SWLS is more of a measurement of an individual's subjective overall evaluation of his/her life rather than affect per se (Diener, 1994). For each item of the SWLS used in this study, responses are made on a 7-point scale from 1 (strongly disagree) to 7 (strongly agree). Sample items include, "The conditions of my life were excellent", and "So far I have gotten the most important things I want in life". Responses were summed up to provide a total life satisfaction score. The SWLS has high internal consistency and high temporal reliability (Diener, 1994; Diener et al., 1985; Park et al., 2009) and moderate or high correlations with other subjective well-being measures. The SWLS converged with the Life Satisfaction Index-A ( $r=.81$; Diener, 1994) and correlated with the scales of Andrews and Withey and Fordyce $(r=.62)$. The Cronbach alpha was reported to be .88 (Park et al., 2009).

Life Engagement Test (LET). The LET (Scheier et al., 2006) consists of 6 items measuring purpose in life by assessing the extent to which an individual engages in activities considered personally valuable and significant. A sample item is, "I value my activities a lot". Responses to each question are made on a 5-point scale from 1 (strongly disagree) to 5 (strongly agree). Three of the six items are negatively-framed (Items 1, 3, and 5) and reverse 
Running Head: CHARACTER STRENGTHS IN SINGAPORE

coded. After converting the reverse-coded items, all the six items are summed to obtain a total score. A higher score indicates a stronger sense of purpose in life for the individual and a greater engagement in personally valued activities.

Good psychometric properties of the LET have been reported in research by Scheier et al. (2006). High factor loadings for all six items of the LET ranged from .57 to .86, with an average of .71, across the samples. Cronbach alphas ranged from .72 to .87 , with an average of .80. Cronbach alphas, ranging from .73 to .83 , were also found to be acceptable in all subgroups which indicate small differences in the psychometric properties of the LET based on gender, age or ethnicity. Test-retest reliability ranged from .61 to .76. The LET has convergent validity with many psychosocial and health-relevant variables such as optimism and depression. It has also discriminant predictive validity with purpose in life and subjective well-being.

\section{Values in Action-Inventory of Strengths (VIA-IS). The VIA-IS (Peterson \&} Seligman, 2004) is a self-report measure comprising 240 items, designed to identify character strengths of an individual. The VIA-IS measures 24 character strengths, with 10 items per strength. The Gallup Organization's Strengths Finder measure was used as the model for the structure of the VIA-IS. The Appendix presents the 240 items adjusted for publication. The VIA-IS uses a 5-point Likert scale of 1 (very much like me) to 5 (very much unlike me) to measure the extent to which respondents rated statements of strengths as relevant to themselves. It has good reliability, validity and test-retest correlations (Peterson \& Seligman, 2004). Responses are averaged across the relevant items to arrive at a score for each of the 24 character strengths.

All the subscales had satisfactory internal consistency with Cronbach alpha coefficients all greater than .70 (Park et al., 2004). Test-retest reliability was acceptable as test-retest correlations $(r \mathrm{~s} \sim .70)$ were substantial for the scales over a 4-month period. Demographic correlations were modest and did not exceed $r=.20$. Females scored higher than males on character strengths for Capacity to Love, Social Intelligence and Kindness. With the exception of gender, demographic variables did not relate to specific character strengths. Park et al. (2006) also presented validity evidence for the VIA-IS. Self-nomination of strengths had substantially correlations $(r s>.5)$ with matching scale scores and ratings by Other Asians and Caucasians such as friends and family members of an individual's top strengths. These yielded moderate correlations ( $r s \sim .3)$ with most of the 24 character strengths scale scores. 
Running Head: CHARACTER STRENGTHS IN SINGAPORE

In the present study, participants made their responses on a similar 5-point Likert scale of 1 (very much like me) to 5 (very much unlike me). All responses on this measure of character strengths were reversed coded to ensure consistency with the other measures.

\section{Procedure}

Participants completed self report measures of each of the four constructs in English on an online survey questionnaire. The survey questionnaire, comprising ten demographic question items and the four measures, were placed online at http://www.surveygizmo.com/s3/498958/janicelee accessible through the identifiable website http:// www.singaporehappiness.com. The website address was made known by word-of mouth, posters at the campus and global social networking websites such as Facebook. Participants were also recruited from among the researcher's friends and acquaintances. Undergraduate students from Singapore's JCU Institute of Higher Learning were also recruited through the Psychology Research Participation Program. Each psychology undergraduate participant received two credit points.

Study participants first viewed the information sheet and then gave their consent by checking the box for it. Each participant was then directed to another web page detailing demographic details needed. Each participant provided basic demographic information required prior to being allowed to proceed to complete the rest of the questionnaire. The order of measures presented was: OHS, SWLS, LET, and VIA-IS. Should an item not be completed on any page, the participant was prompted to do so before proceeding. The items were presented sequentially, several to a web page with the requirement that all the items on a page be responded to before progress was allowed to the next page of the online questionnaire. Only completed questionnaires were used. Responses from individuals who visited the site but did not complete the questionnaire were rejected.

Data collection first began in late March 2011 and ended in early July 2011. The survey took each participant an average of 30 minutes to complete, though no time constraint was pre-programmed by the software.

\section{Results}

Table 2 presents descriptive statistics for the variables based on the whole sample and for each of the four ethnic groups, including the alpha coefficient values. The variables are the 3 happiness orientations deduced from the OHS, the SWLS for measuring life satisfaction, the LET for measuring purpose in life, and the 24 character strengths of the VIA-IS. Internal consistency reliabilities for the three happiness orientations derived from the OHS ranged from .58 (Life of Engagement) to .81 (Life of Pleasure). 
Running Head: CHARACTER STRENGTHS IN SINGAPORE

Table 2

Means, Standard Deviations and Reliability Coefficients; Happiness Orientations, Life Satisfaction, Life Purpose and Character Strengths

\begin{tabular}{|c|c|c|c|c|c|c|c|c|c|c|c|}
\hline \multirow[t]{2}{*}{ Scale/ subscale } & \multicolumn{3}{|c|}{$\begin{array}{l}\text { Entire Sample } \\
\quad(\mathrm{N}=304)\end{array}$} & \multicolumn{2}{|c|}{$\begin{array}{l}\text { Malay } \\
(n=24)\end{array}$} & \multicolumn{2}{|c|}{$\begin{array}{c}\text { Indian } \\
(n=30)\end{array}$} & \multicolumn{2}{|c|}{$\begin{array}{l}\text { Chinese } \\
(n=229)\end{array}$} & \multicolumn{2}{|c|}{$\begin{array}{l}\text { Other Asians } \\
\text { \& Caucasians } \\
\quad(n=21)\end{array}$} \\
\hline & $M$ & $S D$ & $\alpha$ & $M$ & $S D$ & $M$ & $S D$ & $M$ & $S D$ & $M$ & $S D$ \\
\hline Life of Meaning & 20.43 & 4.5 & 0.80 & 22.63 & 3.05 & 21.90 & 3.66 & 20.07 & 4.65 & 19.71 & 4.33 \\
\hline Life of Pleasure & 17.87 & 4.62 & 0.81 & 18.96 & 3.56 & 17.47 & 4.60 & 17.79 & 4.69 & 18.05 & 4.99 \\
\hline Life of Engagement & 17.81 & 3.56 & 0.58 & 19.63 & 3.37 & 16.83 & 3.26 & 17.84 & 3.57 & 16.86 & 3.38 \\
\hline Life Purpose & 21.29 & 6.61 & 0.76 & 24.54 & 4.97 & 21.80 & 8.00 & 20.95 & 6.59 & 20.52 & 5.52 \\
\hline Life Satisfaction & 22.88 & 3.36 & 0.89 & 23.92 & 3.41 & 23.60 & 3.15 & 22.64 & 3.44 & 23.24 & 2.51 \\
\hline Curiosity & 37.38 & 5.23 & 0.84 & 40.54 & 3.97 & 37.17 & 5.34 & 36.98 & 5.31 & 38.43 & 4.26 \\
\hline Love of Learning & 35.19 & 6.17 & 0.85 & 38.83 & 4.98 & 35.30 & 6.40 & 34.83 & 6.24 & 34.81 & 5.24 \\
\hline $\begin{array}{l}\text { Judgment \& Open- } \\
\text { mindedness }\end{array}$ & 39.07 & 4.76 & 0.85 & 41.17 & 4.20 & 39.00 & 4.31 & 38.87 & 4.72 & 38.90 & 6.04 \\
\hline Creativity & 35.97 & 5.93 & 0.88 & 38.17 & 4.33 & 36.80 & 6.09 & 35.64 & 6.12 & 35.86 & 4.68 \\
\hline Social Intelligence & 36.59 & 4.75 & 0.80 & 38.83 & 3.82 & 37.70 & 3.47 & 36.10 & 4.85 & 37.67 & 5.33 \\
\hline Perspective & 36.54 & 5.10 & 0.85 & 38.88 & 4.11 & 38.13 & 4.52 & 35.99 & 5.04 & 37.62 & 6.34 \\
\hline Bravery & 36.05 & 5.14 & 0.82 & 39.17 & 4.33 & 36.77 & 4.55 & 35.46 & 5.11 & 37.90 & 5.55 \\
\hline Perseverance & 36.67 & 5.80 & 0.89 & 38.29 & 5.97 & 36.47 & 5.78 & 36.54 & 5.76 & 36.57 & 6.14 \\
\hline Honesty & 38.84 & 4.41 & 0.80 & 40.50 & 4.15 & 39.17 & 4.83 & 38.66 & 4.31 & 38.48 & 5.01 \\
\hline Kindness & 37.99 & 4.96 & 0.83 & 40.29 & 4.47 & 40.80 & 4.30 & 37.42 & 4.96 & 37.57 & 4.53 \\
\hline Capacity to Love & 37.38 & 5.23 & 0.77 & 39.79 & 4.54 & 39.80 & 4.77 & 37.26 & 4.74 & 39.19 & 3.71 \\
\hline Teamwork & 35.19 & 6.17 & 0.73 & 38.46 & 4.22 & 38.13 & 3.06 & 37.42 & 4.15 & 37.48 & 3.33 \\
\hline Fairness & 39.07 & 4.76 & 0.81 & 40.88 & 3.42 & 41.10 & 3.58 & 38.79 & 4.41 & 39.05 & 4.14 \\
\hline Prudence & 36.22 & 4.97 & 0.78 & 40.54 & 3.97 & 37.17 & 5.34 & 36.98 & 5.31 & 38.43 & 4.26 \\
\hline $\begin{array}{l}\text { Appreciation of } \\
\text { Beauty\& Excellence }\end{array}$ & 35.98 & 5.68 & 0.83 & 38.83 & 4.98 & 35.30 & 6.40 & 34.83 & 6.24 & 34.81 & 5.24 \\
\hline Gratitude & 38.01 & 5.26 & 0.83 & 41.17 & 4.20 & 39.00 & 4.31 & 38.87 & 4.72 & 38.90 & 6.04 \\
\hline Hope & 36.93 & 5.24 & 0.82 & 38.17 & 4.33 & 36.80 & 6.09 & 35.64 & 6.12 & 35.86 & 4.68 \\
\hline $\begin{array}{l}\text { Religiousness \& } \\
\text { Spirituality }\end{array}$ & 36.33 & 7.69 & 0.90 & 38.83 & 3.82 & 37.70 & 3.47 & 36.10 & 4.85 & 37.67 & 5.33 \\
\hline Modesty & 36.58 & 4.89 & 0.79 & 38.88 & 4.11 & 38.13 & 4.52 & 35.99 & 5.04 & 37.62 & 6.34 \\
\hline Humour & 36.98 & 5.88 & 0.89 & 39.17 & 4.33 & 36.77 & 4.55 & 35.46 & 5.11 & 37.90 & 5.55 \\
\hline Zest & 35.29 & 5.68 & 0.85 & 38.29 & 5.97 & 36.47 & 5.78 & 36.54 & 5.76 & 36.57 & 6.14 \\
\hline Forgiveness & 36.36 & 5.97 & 0.88 & 40.50 & 4.15 & 39.17 & 4.83 & 38.66 & 4.31 & 38.48 & 5.01 \\
\hline
\end{tabular}

As the results are enormous, only a summary of the main results is presented here (see Table 3) with the eight hypotheses set against the overall sample and individual ethnic groups $(p=.01)$.

H1: The three happiness orientations were significantly correlated with Life Satisfaction for whole sample, the Chinese and females. H2: Mixed results were obtained. Life Purpose was significantly correlated with Life of Meaning happiness orientation, for the 
whole sample, the Chinese, and between genders. H3: Life Purpose was significantly

correlated with Life Satisfaction for the whole sample, among the Chinese and Indians, and

females. H4: Most character strengths (at least 13 of 24) were significantly correlated with all three happiness orientations (Life of Meaning, Life of Engagement and Life of Pleasure)

for the sample as a whole, among the Chinese and Indians, and females.

Table 3

Summary of Main Results of Study: Hypotheses 1 to 8 against Overall Sample, Ethnic Groups and Gender

\begin{tabular}{|c|c|c|c|c|c|c|c|}
\hline Hypotheses & $\begin{array}{c}\text { Overall } \\
(\mathrm{N}=304)\end{array}$ & $\begin{array}{c}\text { Chinese } \\
(\mathrm{n}=229)\end{array}$ & $\begin{array}{l}\text { Malays } \\
(\mathrm{n}=24)\end{array}$ & $\begin{array}{c}\text { Indians } \\
(\mathrm{n}=30)\end{array}$ & $\begin{array}{l}\text { Others }^{\mathrm{a}} \\
(\mathrm{n}=21)\end{array}$ & $\begin{array}{c}\text { Males } \\
(\mathrm{n}=97)\end{array}$ & $\begin{array}{l}\text { Females } \\
(\mathrm{n}=229)\end{array}$ \\
\hline $\begin{array}{l}\text { H1: The } 3 \\
\text { Happiness } \\
\text { orientations (Life } \\
\text { of Pleasure, Life } \\
\text { of Engagement } \\
\text { and Life of } \\
\text { Meaning) will } \\
\text { correlate with } \\
\text { Life Satisfaction }\end{array}$ & Supported & Supported & No sig. & $\begin{array}{l}\text { only Life of } \\
\text { Meaning sig. } \\
\text { correlated with } \\
\text { Life Satisfaction }\end{array}$ & No sig. & $\begin{array}{l}\text { only Life of } \\
\text { Meaning and } \\
\text { Life of } \\
\text { Engagement sig. } \\
\text { correlated with } \\
\text { Life Satisfaction }\end{array}$ & Supported \\
\hline $\begin{array}{l}\text { H2: The } 3 \\
\text { Happiness } \\
\text { orientations will } \\
\text { correlate with } \\
\text { Life Purpose }\end{array}$ & $\begin{array}{l}\text { Life of Meaning } \\
\text { sig. correlate } \\
\text { with Life } \\
\text { Purpose }\end{array}$ & $\begin{array}{l}\text { Life of Meaning } \\
\text { and Life of } \\
\text { Engagement sig. } \\
\text { correlate with } \\
\text { Life Purpose }\end{array}$ & No sig. & No sig. & No sig. & $\begin{array}{l}\text { Life of Meaning } \\
\text { and Life of } \\
\text { Pleasure sig. } \\
\text { correlate with } \\
\text { Life Purpose }\end{array}$ & $\begin{array}{l}\text { Life of Meaning } \\
\text { sig. correlate } \\
\text { with Life } \\
\text { Purpose }\end{array}$ \\
\hline $\begin{array}{l}\text { H3: That Life } \\
\text { Purpose will } \\
\text { correlate with } \\
\text { Life Satisfaction }\end{array}$ & Supported & Supported & No sig. & Supported & No sig. & No sig. & Supported \\
\hline $\begin{array}{l}\text { H4: That most of } \\
\text { the } 24 \text { character } \\
\text { strengths }{ }^{\mathrm{b}} \text { will } \\
\text { correlate with } \\
\text { each Happiness } \\
\text { orientations (Life } \\
\text { of Pleasure, Life } \\
\text { of Engagement } \\
\text { and Life of } \\
\text { Meaning) }\end{array}$ & $\begin{array}{l}\text { At least } 13 \text { of } 24 \\
\text { character } \\
\text { strengths sig. } \\
\text { correlated with } \\
\text { all three } \\
\text { orientations to } \\
\text { Happiness }\end{array}$ & $\begin{array}{l}\text { At least } 13 \text { of } 24 \\
\text { character } \\
\text { strengths sig. } \\
\text { correlated with } \\
\text { all three } \\
\text { orientations to } \\
\text { Happiness }\end{array}$ & $\begin{array}{l}\text { Character } \\
\text { strengths } 1 \text { to } 11 \\
\text { sig. correlated } \\
\text { with each } \\
\text { Happiness } \\
\text { orientation }\end{array}$ & $\begin{array}{l}\text { Character } \\
\text { strengths } 1 \text { to } 11 \\
\text { sig. correlated } \\
\text { with each } \\
\text { Happiness } \\
\text { orientation }\end{array}$ & $\begin{array}{l}\text { Character } \\
\text { strengths } 1 \text { to } 11 \\
\text { sig. correlated } \\
\text { with each } \\
\text { Happiness } \\
\text { orientation }\end{array}$ & $\begin{array}{l}\text { Most character } \\
\text { strengths sig. } \\
\text { correlated with } \\
\text { Life of Meaning } \\
\text { and Life of } \\
\text { Engagement }\end{array}$ & $\begin{array}{l}\text { At least } 13 \text { of } 24 \\
\text { character } \\
\text { strengths sig. } \\
\text { correlated with } \\
\text { all three } \\
\text { orientations to } \\
\text { Happiness }\end{array}$ \\
\hline $\begin{array}{l}\text { H5: That top } 5 \\
\text { character } \\
\text { strengths most } \\
\text { strongly } \\
\text { correlated with } \\
\text { Life Satisfaction } \\
\text { are Zest, Hope, } \\
\text { Capacity to } \\
\text { Love, Curiosity } \\
\text { and either } \\
\text { Gratitude or } \\
\text { Perseverance }\end{array}$ & $\begin{array}{l}\text { Zest, Hope, } \\
\text { Capacity to } \\
\text { Love, Curiosity } \\
\text { and Gratitude } \\
\text { were top five } \\
\text { character } \\
\text { strengths } \\
\text { correlated with } \\
\text { Life Satisfaction }\end{array}$ & $\begin{array}{l}\text { Zest, Hope, } \\
\text { Capacity to } \\
\text { Love, Curiosity } \\
\text { and Gratitude } \\
\text { were top five } \\
\text { character } \\
\text { strengths } \\
\text { correlated with } \\
\text { Life Satisfaction }\end{array}$ & No sig. & $\begin{array}{l}\text { Bravery and } \\
\text { Religiousness } \\
\text { and Spirituality, } \\
\text { among top five } \\
\text { character } \\
\text { strengths, in } \\
\text { addition to three } \\
\text { top character } \\
\text { strengths (Zest, } \\
\text { Capacity to } \\
\text { Love, and } \\
\text { Gratitude) }\end{array}$ & No sig. & $\begin{array}{l}\text { Zest, Hope, } \\
\text { Gratitude and } \\
\text { Curiosity and } \\
\text { Perspective } \\
\text { among top five } \\
\text { closely } \\
\text { associated with } \\
\text { Life Satisfaction }\end{array}$ & $\begin{array}{l}\text { Zest, Hope, } \\
\text { Capacity to } \\
\text { Love, Curiosity } \\
\text { and Gratitude } \\
\text { were top five } \\
\text { character } \\
\text { strengths closely } \\
\text { associated with } \\
\text { Life Satisfaction }\end{array}$ \\
\hline $\begin{array}{l}\text { H6: That top } 5 \\
\text { character } \\
\text { strengths (Zest, } \\
\text { Hope, Capacity } \\
\text { to Love, } \\
\text { Curiosity and } \\
\text { Gratitude) } \\
\text { correlating with } \\
\text { Life Purpose will } \\
\text { also correlate } \\
\text { with Life } \\
\text { Satisfaction }\end{array}$ & Supported & Supported & $\begin{array}{l}\text { Curiosity } \\
\text { associated with } \\
\text { both Life } \\
\text { Purpose and Life } \\
\text { Satisfaction }\end{array}$ & $\begin{array}{l}\text { Zest, Gratitude, } \\
\text { Capacity to } \\
\text { Love, and Hope } \\
\text { sig. correlated } \\
\text { with Life } \\
\text { Satisfaction, and } \\
\text { Life Purpose } \\
\text { Curiosity } \\
\text { associated } \\
\text { with both Life } \\
\text { Purpose and Life } \\
\text { Satisfaction }\end{array}$ & No sig. & $\begin{array}{l}\text { Zest, Hope, } \\
\text { Capacity to } \\
\text { Love, and } \\
\text { Curiosity sig. } \\
\text { correlated with } \\
\text { Life Purpose and } \\
\text { Life Satisfaction } \\
\text { Gratitude sig. } \\
\text { correlated only } \\
\text { with Life } \\
\text { Satisfaction }\end{array}$ & $\begin{array}{l}\text { Zest, Hope, } \\
\text { Capacity to } \\
\text { Love, and } \\
\text { Curiosity sig. } \\
\text { correlated with } \\
\text { Life Purpose and } \\
\text { Life Satisfaction } \\
\text { Gratitude sig. } \\
\text { correlated with } \\
\text { Life Purpose and } \\
\text { Life Satisfaction }\end{array}$ \\
\hline
\end{tabular}


Table 3 Summary of Main Results of Study (continued)

\begin{tabular}{|c|c|c|c|c|c|c|c|}
\hline $\begin{array}{l}\text { H7: That } \\
\text { particular } \\
\text { character } \\
\text { strengths will } \\
\text { most associate } \\
\text { with each } \\
\text { Happiness } \\
\text { orientation }\end{array}$ & & & & & & & \\
\hline $\begin{array}{l}\text { i.e., } \\
\text { Religiousness } \\
\text { and Spirituality, } \\
\text { Gratitude, Hope, } \\
\text { Zest, and } \\
\text { Curiosity most } \\
\text { associated with } \\
\text { Life of Meaning }\end{array}$ & $\begin{array}{l}\text { Curiosity, } \\
\text { Gratitude, } \\
\text { Perspective, } \\
\text { Kindness and } \\
\text { Zest sig. } \\
\text { associated with } \\
\text { Life of Meaning }\end{array}$ & $\begin{array}{l}\text { Curiosity as a top } \\
\text { character } \\
\text { strength most } \\
\text { associated with } \\
\text { Life of Meaning }\end{array}$ & $\begin{array}{l}\text { Curiosity as a top } \\
\text { character } \\
\text { strength most } \\
\text { associated with } \\
\text { Life of Meaning }\end{array}$ & $\begin{array}{l}\text { Curiosity as a top } \\
\text { character } \\
\text { strength most } \\
\text { associated with } \\
\text { Life of Meaning }\end{array}$ & $\begin{array}{l}\text { Creativity and } \\
\text { Perseverance as } \\
\text { character } \\
\text { strengths most } \\
\text { associated with } \\
\text { Life of Meaning }\end{array}$ & $\begin{array}{l}\text { Curiosity, Hope, } \\
\text { Religiousness } \\
\text { and Spirituality, } \\
\text { Capacity to Love } \\
\text { and Appreciation } \\
\text { of Beauty and } \\
\text { Excellence most } \\
\text { associated with } \\
\text { Life of Meaning }\end{array}$ & $\begin{array}{l}\text { Gratitude, } \\
\text { Perspective, } \\
\text { Curiosity, } \\
\text { Bravery and } \\
\text { Kindness as the } \\
\text { top five character } \\
\text { strengths most } \\
\text { associated with } \\
\text { Life of Meaning }\end{array}$ \\
\hline $\begin{array}{l}\text { i.e., Zest, } \\
\text { Curiosity, Hope, } \\
\text { Perseverance, } \\
\text { and Perspective } \\
\text { most associated } \\
\text { with the Life of } \\
\text { Engagement }\end{array}$ & $\begin{array}{l}\text { Creativity, Zest, } \\
\text { Curiosity, } \\
\text { Bravery and } \\
\text { Perspective } \\
\text { associated } \\
\text { mostly with Life } \\
\text { of Engagement }\end{array}$ & $\begin{array}{l}\text { Zest, Creativity, } \\
\text { Curiosity, } \\
\text { Perspective and } \\
\text { Perseverance } \\
\text { most associated } \\
\text { with Life of } \\
\text { Engagement }\end{array}$ & 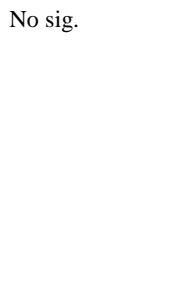 & $\begin{array}{l}\text { Curiosity most } \\
\text { associated with } \\
\text { Life of } \\
\text { Engagement }\end{array}$ & $\begin{array}{l}\text { Fairness, } \\
\text { Honesty, } \\
\text { Prudence and } \\
\text { Judgement and } \\
\text { Open- } \\
\text { mindedness most } \\
\text { associated with } \\
\text { Life of } \\
\text { Engagement }\end{array}$ & $\begin{array}{l}\text { Zest, Creativity, } \\
\text { Curiosity, } \\
\text { Perspective and } \\
\text { Perseverance } \\
\text { most associated } \\
\text { with Life of } \\
\text { Engagement }\end{array}$ & $\begin{array}{l}\text { Creativity, } \\
\text { Curiosity, Zest, } \\
\text { Bravery and } \\
\text { Love of Learning } \\
\text { as top five } \\
\text { character } \\
\text { strengths most } \\
\text { associated with } \\
\text { Life of } \\
\text { Engagement }\end{array}$ \\
\hline $\begin{array}{l}\text { i.e., Humor, Zest, } \\
\text { Hope, Social } \\
\text { Intelligence, and } \\
\text { Capacity to Love } \\
\text { most associated } \\
\text { with Life of } \\
\text { Pleasure }\end{array}$ & $\begin{array}{l}\text { Humour, } \\
\text { Creativity, } \\
\text { Curiosity, } \\
\text { Appreciation of } \\
\text { Beauty and } \\
\text { Excellence, and } \\
\text { Zest associated } \\
\text { most with Life of } \\
\text { Pleasure }\end{array}$ & $\begin{array}{l}\text { Humour, } \\
\text { Creativity, Social } \\
\text { Intelligence, } \\
\text { Kindness and } \\
\text { Appreciation of } \\
\text { Beauty and } \\
\text { Excellence, most } \\
\text { associated with } \\
\text { Life of Pleasure }\end{array}$ & $\begin{array}{l}\text { Only character } \\
\text { strength of } \\
\text { Curiosity } \\
\text { most associated } \\
\text { with Life of } \\
\text { Pleasure }\end{array}$ & No sig. & $\begin{array}{l}\text { Humour as } \\
\text { character } \\
\text { strength, and } \\
\text { Curiosity another } \\
\text { character } \\
\text { strength most } \\
\text { associated with } \\
\text { Life of Pleasure }\end{array}$ & $\begin{array}{l}\text { Curiosity, Zest, } \\
\text { Appreciation of } \\
\text { Beauty and } \\
\text { Excellence, } \\
\text { Humour and } \\
\text { Kindness most } \\
\text { associated with } \\
\text { Life of Pleasure }\end{array}$ & $\begin{array}{l}\text { Creativity, } \\
\text { Humour, } \\
\text { Bravery, Social } \\
\text { Intelligence, and } \\
\text { Appreciation of } \\
\text { Beauty and } \\
\text { Excellence as top } \\
\text { five character } \\
\text { strengths most } \\
\text { associated with } \\
\text { Life of Pleasure }\end{array}$ \\
\hline $\begin{array}{l}\text { H8: That Life } \\
\text { Purpose, all three } \\
\text { happiness } \\
\text { orientations } \\
\text { (Life of Pleasure, } \\
\text { Life of } \\
\text { Engagement and } \\
\text { Life of } \\
\text { Meaning), and } \\
\text { character } \\
\text { strengths of } \\
\text { Hope, Gratitude, } \\
\text { Capacity to Love } \\
\text { and Zest (with no } \\
\text { mediating paths } \\
\text { involving the } \\
\text { happiness } \\
\text { orientations) will } \\
\text { contribute to } \\
\text { predicting Life } \\
\text { Satisfaction }\end{array}$ & $\begin{array}{l}\text { Life Purpose and } \\
\text { character } \\
\text { strengths of } \\
\text { Capacity to Love } \\
\text { and Gratitude } \\
\text { directly } \\
\text { contributed to } \\
\text { Life Satisfaction }\end{array}$ & & & & & & \\
\hline
\end{tabular}

Note: a. Others refer to Asians and Caucasians. b. The 6 Virtues (with character strengths in parentheses, totalling 24) are Wisdom and Knowledge (Creativity, Curiosity, Judgment and Open-mindedness, Love of Learning, and Perspective),

Courage (Honesty, Bravery, Perseverance and Zest), Humanity (Kindness, Capacity to Love and Social Intelligence), Justice (Fairness, Leadership and Teamwork), Temperance (Forgiveness, Modesty, Prudence and Self-regulation), and Transcendence (Appreciation of Beauty and Excellence, Gratitude, Hope, Humour, and Religiousness and Spirituality).

\section{H5: Zest, Hope, Capacity to Love, Curiosity and Gratitude were the top five character} strengths that correlated with Life Satisfaction for the entire sample as a whole, among the Chinese, and females. H6: The top five character strengths (Zest, Hope, Capacity to Love, Curiosity and Gratitude) which significantly correlated with Life Satisfaction, also significantly correlated with Life Purpose for the sample as a whole, and among the Chinese. 
The Indians had four of five character strengths (Zest, Gratitude, Capacity to Love, and Hope) correlating simultaneously with Life Satisfaction and Life Purpose. The males and females had four of the five character strengths (Zest, Hope, Capacity to Love, and Curiosity) significantly correlated with both Life Purpose and Life Satisfaction. H7: Mixed results were obtained. The sample as a whole found that: Curiosity, Gratitude, Perspective, Kindness and Zest to be significantly associated with Life of Meaning; Creativity, Zest, Curiosity, Bravery and Perspective were associated mostly with Life of Engagement; and Humour, Creativity, Curiosity, Appreciation of Beauty and Excellence, and Zest were associated most with Life of Pleasure. H8: Life Purpose and character strengths of Capacity to Love and Gratitude were found directly to have contributed to Life Satisfaction.

\section{Discussion}

The present study has investigated eight hypotheses on: (1) the relationships among happiness approaches, character strengths, life satisfaction and life purpose; and (2) to identify robust character strengths valued by the ethnic groups in Singapore in relation to the pursuit of happiness, life purpose and life satisfaction. As the sample sizes of the ethnic groups vary greatly, results of the three smaller ethnic groups require cautious interpretation.

\section{Happiness and Life Satisfaction}

The Singaporean sample, in general, is inclined to endorse all three happiness orientations for a satisfying life, similar to findings of Peterson, et al. (2005). However, this finding is particular for the Chinese and females. When each of the four ethnic groups is considered separately, each showed highest scores on Life of Meaning as a happiness orientation. This implies that generally Singapore residents endorse a life of meaning and purpose, above having an engaging or pleasure seeking life. This finding is similar to that found in the 31 Singapore participants in the study by Park et al. (2009).

\section{Happiness and Life Purpose}

The Singaporean sample, in general, and between genders in particular, is inclined to endorse the meaningful life route to happiness as the only happiness orientation significantly associated with Life Purpose. This is not as purported that all three happiness routes will be significantly associated with life purpose (Scheier et al., 2006; Steger et al., 2006). The finding that the Chinese have Life of Meaning and Life of Engagement happiness significantly associated with Life Purpose, supports the views held by Marsh et al. (2003) and Steger et al. (2006) that having meaning and purpose in life as essential for well-being. The Life of Meaning and Life of Engagement happiness orientations, with the focus on being a part of something larger than self through belonging and being of service to others, and 
through using personal strengths and talents to meet life challenges, mean that individuals must demonstrate relevant activities and behaviours (Duckworth et al., 2005). The finding that the other ethnic groups have not been found to have the meaning and engagement routes to happiness contributing significantly to achieving a sense of purpose in life is possibly due to their small sample sizes. The finding of Life of Pleasure being the only happiness orientation to have a less robust but significant association with Life Purpose among the Malays and Indians suggests the possibility of a difference in how members in these two minority groups view the link of pleasure with life meaning, when compared to the majority Chinese. To the Malays and Indians, maximizing positive emotions such as joy and love, and reducing negative emotions, significantly contributes to their sense of life purpose.

Nevertheless, this observation will need further investigation to be conclusive.

\section{Life Satisfaction and Life Purpose}

The Singaporean sample, in general, is inclined to endorse life purpose with life satisfaction. Satisfaction with life is linked to reports of presence of meaning in life (Steger et al., 2006). Being able to find meaning and sense in our daily lives and our existence is crucial to health and well-being (Marsh et al., 2003). However, this finding is particular for the Chinese, Indians and females. The correlation of Life Purpose-meaning of life with life satisfaction concurs with opinions of Park et al. (2010), in that having substantial meaning in life relates to greater life satisfaction. The non-significant findings of the Malays, Other Asians and Caucasians, and males, are most probably due to their small sample sizes.

\section{Happiness and Character Strengths}

The finding of the Singapore sample that most character strengths (from 15 to all 24) were significantly correlated with each of the orientations to happiness replicates the results of the study by Peterson et al. (2007). However, this finding is particular for the Chinese and females. The non-significant findings of the Malays, Other Asians and Caucasians, and males, are most probably due to their small sample sizes. These findings, based on ethnicity, agree with the viewpoint of Biswas-Diener (2006), that even though people from different cultures may recognize and acknowledge the existence, development and desirability of personal strengths, differences can exist among and within cultures on perceived importance of specific strengths. The ethnic groups in Singapore have variations in language, cultural and spiritual practices and traditions, and vastly different histories of heritage which originated from different geographical parts of the world. These backgrounds are likely to have influenced the nurturance of specific character strengths (Biswas-Diener, 2006). 
Running Head: CHARACTER STRENGTHS IN SINGAPORE

\section{Top Character Strengths and Life Satisfaction}

As with the study by Peterson et al. (2007), the top five strengths of the Singapore sample most strongly correlated with life satisfaction are Zest, Hope, Capacity to Love, Curiosity and Gratitude; especially for the Chinese and females. These constitute core strengths that people around the world aspire to instill and nurture in themselves and others in order to achieve a life worth living (Park et al., 2004; Peterson et al., 2007). The Indians and the Chinese value commonly Zest, Gratitude and Capacity to Love, which Park et al. (2004) define as strengths of the heart. However, the Indians also associate Bravery, and Religiousness and Spirituality, with Life Satisfaction, compared with Hope and Curiosity of the Chinese. These findings of the impact of character strengths on satisfaction in life, based on ethnicity and gender can be discussed more broadly using the classifications of virtues suggested by Peterson and Seligman (2004). The character strengths of Zest and Bravery are character strengths under the virtue of courage whereas the character strength of Curiosity is under the virtue of wisdom and knowledge. Gratitude, Hope, and Religiousness and Spirituality are amongst character strengths that comprise the virtue of transcendence. The character strength of Capacity to Love is amongst the strengths under the virtue of humanity. The Indians and Chinese seem to share one or more character strengths pertaining to the virtues of courage and transcendence. It is interesting that both ethnic groups value at least an emotional strength of courage that exercises the will to undertake and complete tasks in the face of difficult challenges. These two ethnic groups also seem to value one or more strengths under the virtue of transcendence that foster connections to "something bigger than oneself" as providing meaning in life. This may imply that these two ethnic groups are able to find a common ground on which all can enhance life satisfaction without having to compromise on their cultural values which they as individuals, and their ethnic communities, interpret as intrinsically significant.

\section{Top Character Strengths and Life Purpose}

The top five character strengths (Zest, Hope, Capacity to Love, Curiosity and Gratitude) which significantly correlated with Life Satisfaction, also significantly correlated with Life Purpose for the Singapore sample and among the Chinese. This finding is particular for the Indians and females. The character strengths of Zest and Curiosity emphasize the here and now whereas Hope emphasizes looking forward to a happy future, and Capacity to Love emphasizes good relationships with others (Park et al., 2004). It implies that while having a preference to focus on the present (with Zest and Curiosity), they also keep in mind (with Hope), a future that is yet to be- - belief in working hard to achieve a good future and 
expecting the best in it. It is also noted that the Indians and females placed significant importance on valuing relationships through sharing and caring, as indicated by the significant association of Capacity to Love with Life Purpose. Overall, it can be deduced that the people of Singapore have the requisites necessary to desire to cultivate and nurture their character strengths of Hope, Zest and Curiosity so as to make better sense of the meaning and purpose in living in the present, while also having a future orientation.

\section{Character Strengths and Happiness Orientations}

The findings supported somewhat that particular character strengths are most associated with each happiness orientation, as suggested by Peterson et al. (2007). Overall results suggest that with regard to pursuing a pleasurable life, openness to new possibilities (Curiosity and Creativity) and greater appreciation of life (Appreciation of Beauty and Excellence and Zest), posited by Peterson et al. (2008), together with the relief that Humour produces in coping with emotions (Peterson et al., 2006), are considered essential qualities by Singapore residents. The character strength of Humour is found to be closely associated with Life of Pleasure happiness orientation in the whole sample and in each ethnic group.

An interesting observation is that the Chinese, in addition to having Humour and Zest, also have Social Intelligence, Kindness, and Creativity most associated with a Life of Pleasure happiness orientation. The Other Asians and Caucasians is observed to share common character strengths of Humour, Zest and Kindness with the Chinese in associating character strengths with a pleasurable life route to happiness. The Other Asians and Caucasians are also noted to share the character strength of Curiosity as one of the top five character strengths most associated with Life of Pleasure happiness orientation with the Malays. It can be deduced from this present study that Singapore residents, like other samples studied, associate Humour and Zest as character strengths preferred for a pleasurable life. In collectivistic Asian cultures in which maintaining good relationships with others is a main concern in daily living (Suh \& Oishi, 2002), the close association of character strength of Kindness with a pleasurable life is very probable.

In the present Singapore study sample the character strengths of Creativity, Curiosity, Bravery, Perspective and Zest are most associated with Life of Engagement. Perseverance and Hope are, however, not on the top five ranking list; whereas Peterson et al. (2007) found Hope and Perseverance most associated with Life of Engagement happiness orientation. The Singapore sample seems to endorse more of character strengths under the virtue of wisdom and knowledge (with Creativity, Curiosity and Perspective) and strengths under the virtue of courage (with Bravery and Zest) in their pursuit of an engaged life happiness route, than the 
U.S. and Swiss samples of Peterson et al. (2007). These U.S. and Swiss samples, in addition to cognitive and courage-focused strengths, also endorse the virtue of transcendence with Hope in their pursuit of an engaged life happiness route. The present finding on the relationships of character strengths and Life of Engagement happiness orientation suggests that East Asians tend to value achievement and mastery more and to view happiness differently, at least in comparison to people in Latin nations (Diener \& Scollon, 2003). In the Singapore context, where collectivistic traditions prevail, the experiences of achievement of personal goals and the pleasant feelings from that achievement can contribute to well-being; happiness and life satisfaction (Tamir \& Gross, 2011).

In examining the whole sample, the character strengths most associated with Life of Meaning in this study are Curiosity, Gratitude, Zest, Perspective and Kindness; whereas Peterson et al. (2007) have found Religiousness and Spirituality, and Hope, along with Curiosity, Gratitude, and Zest in their study. Bermant et al. (2011) explain that the strong inclination to gain knowledge about life in the search for meaning in life, (that is, to be curious) and to become aware of and thankful for the good in life (that is, to be grateful), may be influenced by cultural underpinnings. One such underlying cultural philosophy is the value given to appreciating and giving thanks for the good in life. The classification of both Gratitude, and Religiousness and Spirituality, as character strengths within the broader virtue of transcendence, which aims to connect the self to a larger scheme of things in the world to provide meaning and purpose in life, suggests that these two character strengths share considerable similarity. Religiousness and Spirituality in Asian collectivist societies, with their concepts of selflessness, abandonment of personal gains and non-attachment, may not be accurately captured by the items in the VIA-IS or the OHS which are based on individualist societal concepts and language (Bermant et al., 2011).

\section{Predictors of Life Satisfaction}

The present findings endorsed that Life Purpose and character strengths of Gratitude and Capacity to Love (with no mediating paths involving the happiness orientations) significantly contribute to predicting Life Satisfaction. If one can nurture the Capacity to Love, which refers to being able to value relations with other people and be close to them through reciprocated sharing and caring, satisfaction in life will increase. Gratitude is defined as being aware of and thankful of the good things that occur in life. These two character strengths reflect a way to be happy beyond the meaningful, engaged and pleasurable happiness orientations (Peterson et al., 2007). As Bermant et al. (2011) and Compton (2005) have argued, just as there are different ways in which happiness is defined, experienced and 
Running Head: CHARACTER STRENGTHS IN SINGAPORE

evaluated across cultures, so the same applies to life's purpose which is differently defined, experienced and evaluated in different cultures.

Figure 1 (based on hierarchical multiple regression analyses performed in the Results section) shows the direct and indirect pathways predicting life satisfaction.

Figure 1

Path diagram; only pathways significant at $p<.01$ are shown

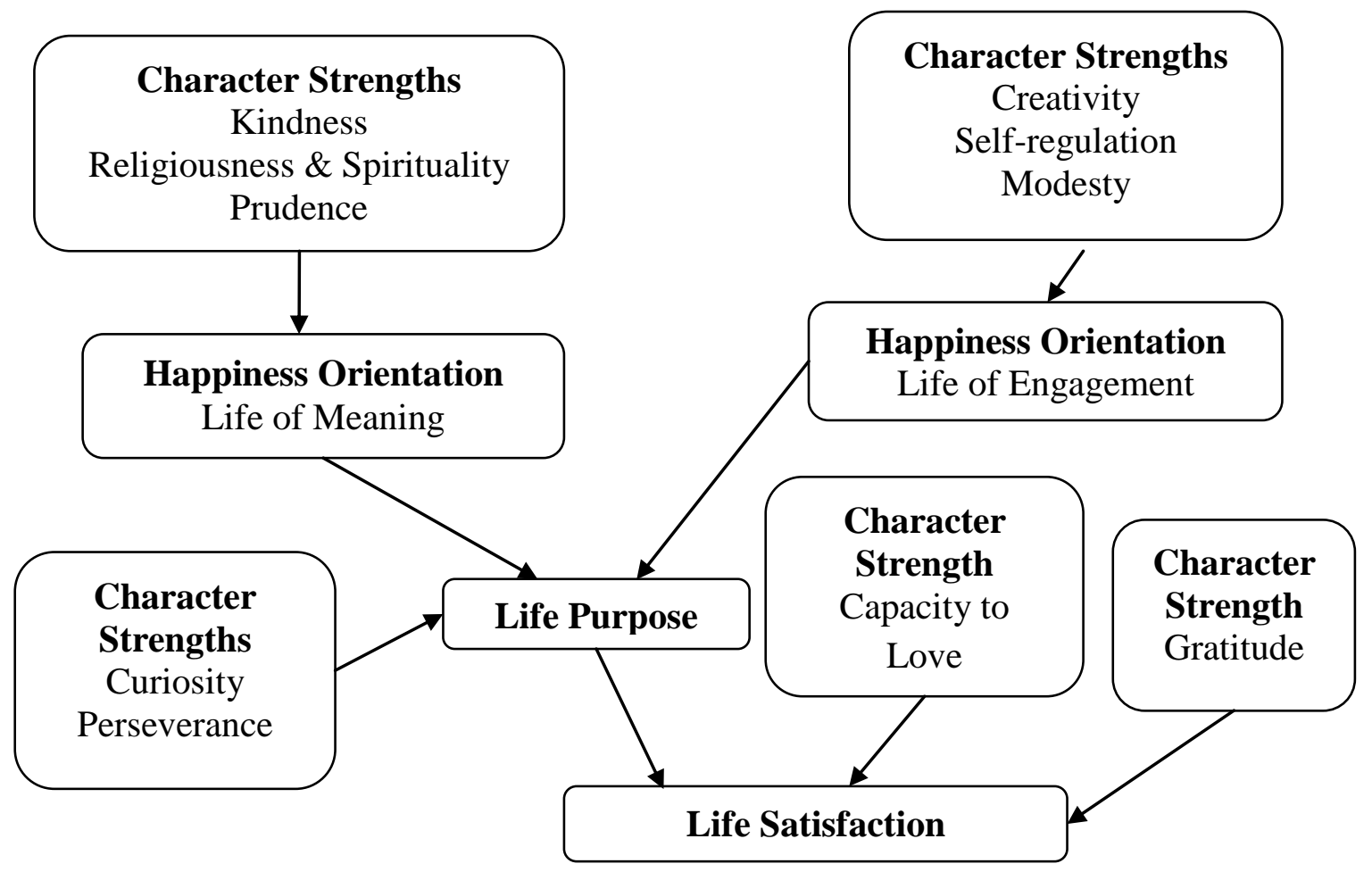

Whereas Appreciation of Beauty and Excellence, Hope and Humour are direct predictors of pleasurable happiness orientation in the study by Peterson et al. (2007), Curiosity and Creativity are found to be desired for a pleasurable life within the Singapore participants. Asian doctrine emphasizes mastery and achievement over and beyond instant gratification brought upon by the mere experience of pleasure (Bermaut et al., 2011; Suh \& Oishi, 2002). Therefore, it can be deduced that given the emphasis on mastery and achievement in many Asian cultures, the cognitive strengths of Curiosity and Creativity emphasizing openness and flexibility to new possibilities are considered to be important in 'feeling good' in the long run than a fleeting moment. The character strength of Religiousness and Spirituality, being negatively associated with Life of Pleasure happiness orientation (as found by Peterson et al., 2007), can be explained in that seeking connection to something bigger than oneself requires effort and serious contemplation on the part of the individual. These processes are often not considered pleasurable from a hedonic viewpoint, 
which explains the inverse relationship of these two character strengths with the pleasurable life happiness orientation. If one desires the experience of instantly gratifying positive emotions more than the longer term outcomes of achievement and mastery, then nurturing the character strengths of Religiousness and Spirituality will obstruct the path of happiness through pleasure that is based on positive affect.

Modesty, Self-regulation and Creativity were found in the present sample to directly predict the Life of Engagement happiness orientation. Creativity has also been found by Peterson et al. (2007) to be a predictor of engagement happiness orientation. What seems interesting in the present sample is that the lesser endorsed character strengths of Selfregulation and Modesty are found to be predictive of engaged life happiness orientation. A plausible explanation offered by Bermaut et al. (2011) is that in the Asian ethos, the ability to be self-disciplined in one's feelings and behaviours to achieve collectivist good for its community is very much valued over personal gains of the individual. Collectivistic cultures, with their concern to maintain harmonious relationships with other people, promote instilling values (such as Modesty and Self-regulation) emphasizing interpersonal harmony (Suh \& Oishi, 2002). The individual therefore has to be alert to social cues to adjust according to the needs and expectations of others and their communities to attain optimal societal functioning. The inverse relationship of Modesty with Life of Engagement happiness orientation found in the present study implies that if one is more inclined to be pursuing a Life of Engagement happiness orientation to attain personal happiness, the less the character strength of Modesty is endorsed, the better it is for the pursuit of an engaging life focused on tasks and outcomes/achievement.

In the present data, two happiness orientations, Life of Meaning positively and Life of Engagement negatively contributed significantly to Life Purpose. It suggests that the more life is viewed as being focused on doing personally meaningful valued activities, the less the person is required to be in a state of being engagingly focused and engrossed in tasks at the moment. It is possible the opposing finding may be the result of differences in interpretation of individualist language. Those imbued with collectivist wisdom doctrine may find this difficult to comprehend if the focus is on social cohesiveness over personal accomplishment and concern for personal gains from one's actions (Bermaut et al., 2011). Perhaps, for future research, if the LET and OHS can be translated into collectivist language to better reflect Asian values and understanding of importance of the relationship of self with the society at large, results can then be compared, thus testing the speculation of such reasoning. 
Running Head: CHARACTER STRENGTHS IN SINGAPORE

Life Purpose is a positive significant predictor of Life Satisfaction, implying with an increased sense of purpose in life, satisfaction in life also increases. Two character strengths, namely Curiosity and Perseverance, are found to be directly significantly predictive of Life Purpose. Additionally, the character strengths of Capacity to Love and Gratitude also directly predict Life Satisfaction. Whereas the study by Peterson et al. (2007) found Hope, Zest, Capacity to Love and Gratitude to be direct and strong predictors of Life Satisfaction, this present study, did not find Hope and Zest contributing directly to predicting Life Satisfaction or Life Purpose.

Only two happiness orientations, Life of Meaning and Life of Engagement, are also direct predictors of Life Purpose but none of the happiness orientations are direct predictors of satisfaction with life. This finding does not replicate that of Peterson et al. (2007), in which all three happiness orientations are direct predictors of Life Satisfaction. The contribution of Life Purpose predicting Life Satisfaction is not surprising, as Park et al. (2010) have found that having a sense of purpose in life is crucial for general health and well-being. Life Purpose as measured by the LET will require further investigation regarding its mediating role in associating character strengths and happiness orientations with Life Satisfaction as this is the first time the LET is used in a study on character strengths, happiness orientations, life purpose and life satisfaction.

\section{Mean Differences between Genders}

Although differences between genders are found in the present data, they are not considered to be of practical significance. This latter finding supports the standpoint of Linley et al. (2007) that, in general, more similarities than differences between the genders are observed.

\section{Mean Differences between Ethnic Groups}

The ethnic groups are generally similar to one another on levels of happiness and their experience of life to be purposeful and satisfying. Differences among the ethnic groups are statistically significant for the twelve character strengths of Perspective, Bravery, Kindness, Capacity to Love, Fairness, Leadership, Appreciation of Beauty and Excellence, Gratitude, Religiousness and Spirituality, Modesty, Humour, and Zest. Malays place significantly higher values on having character strengths of Perspective, Bravery, and Zest than Chinese. Data suggest that the Indians value character strengths of Capacity to Love, Fairness and Leadership more than the Chinese. The means scores of the Malays on character strengths of Modesty and Appreciation of Beauty and Excellence are significantly higher than those by the Chinese and Other Asians and Caucasians. 
Malays and Indians value Kindness and Humour more than the Chinese. The Malays place the most emphasis on importance of Religiousness and Spirituality, followed by the Indians. The Chinese and the Other Asians and Caucasians do not place such emphasis on the value of being connected to a higher-order being larger than being a human being. There are significant differences in means scores on Gratitude when comparing all four ethnic groups. The Malays have higher and significantly different scores on Gratitude when compared with the Chinese and Other Asians and Caucasians. The means scores on Gratitude by the Indians are also significantly different from those by the Chinese. The character strength of Gratitude is valued more by the Indians, when compared with the Chinese. The Indians, the Malays and Other Asians and Caucasians show no significant differences in means scores on Gratitude. Among the ethnic groups, Gratitude is most valued by the Malays. The means scores on Gratitude by the Malays and Indians are significantly different from the Chinese who have the lowest means scores for Gratitude. The Malays are also found to have significantly higher scores on Gratitude, when compared with the group of Other Asians and Caucasians. Table 4 summarizes significant means differences among the four ethnic groups.

Table 4

Character Strengths Differences among Ethnic Groups

\begin{tabular}{|c|c|c|}
\hline \multicolumn{2}{|c|}{ Comparing Ethnic Groups } & Significant Means Differences found in \\
\hline Malays with & Chinese & $\begin{array}{l}\text { Perspective }(\eta 2=.04) \\
\text { Zest }(\eta 2=.04) \\
\text { Bravery }(\eta 2=.05)\end{array}$ \\
\hline Indians with & Chinese & $\begin{array}{l}\text { Fairness }(\eta 2=.04) \\
\text { Leadership }(\eta 2=.04) \\
\text { Capacity to Love }(\eta 2=.05)\end{array}$ \\
\hline Malays with & $\begin{array}{l}\text { Chinese and Other Asians and } \\
\text { Caucasians }\end{array}$ & $\begin{array}{l}\text { Modesty }(\eta 2=.05) \\
\text { Appreciation of Beauty and Excellence } \\
(\eta 2=.04)\end{array}$ \\
\hline Malays and Indians with & Chinese & $\begin{array}{l}\text { Kindness }(\eta 2=.06) \\
\text { Humour }(\eta 2=.06)\end{array}$ \\
\hline Malays and Indians with & $\begin{array}{l}\text { Chinese and Other Asians and } \\
\text { Caucasians }\end{array}$ & Religiousness and Spirituality $(\eta 2=.08)$ \\
\hline Malays with & $\begin{array}{l}\text { Chinese and Other Asians and } \\
\text { Caucasians }\end{array}$ & Gratitude $(\eta 2=.04)$ \\
\hline Indians with & Chinese & \\
\hline
\end{tabular}

\section{Implications for Practice}

If psychologists understand and believe that nurturance of positive human qualities such as courage, hope, gratitude, meaning and purpose in life can reinforce resilience and a better quality of life, treatment of clients will take on an improved route. Relieving people of 
emotional suffering is important but it is not sufficient. Psychologists in Singapore can provide better treatment interventions when they support and encourage the enhancement of life's purpose and life's satisfaction while nurturing valued character strengths such as Zest, Hope, Curiosity, Capacity to Love, Gratitude and Kindness. Strategies are needed to focus on teaching people who have mental health conditions or who are at risk of poor mental health to identify valued character strengths and learn when to use these personal strengths. Strategies for nurturing well-being can foster resilience for life's misfortunes and for psychological disorders. The attainment of life's purposes and life's satisfaction through emphasizing routes to happiness and the development of character strengths also have crucial roles in informing what makes life worth living, taking into consideration the adaptive and emotional aspects for optimal human functioning.

\section{Limitations and Directions for Future Studies}

The length of the 240 question VIA-IS items was the main complaint of participants as they had to answer all 279 question items in one setting. Many participants were unfamiliar with using the Internet for psychological research studies. Feedback revealed that some had taken one hour to complete the whole survey when the survey should have taken about 30 minutes to complete. It is possible that participants were not responding appropriately to the questionnaire as some responses were at one extreme score consistently for many question items at a stretch before any variation in responses were made. Thus fatigue in participants during completion of the questionnaires must be taken into consideration when interpreting the results.

Recruitment over the internet has its limitations in terms of concerns on data quality (Kraut et al., 2004). Although the design of this present survey has carefully put in place strategies for guarding against poor or contaminated data, sample biases pertaining to accessibility of the Internet to individuals across gender, education and age can still be present to confound the results. There are those without access to Internet services (older, retired or uneducated), those who participate to damage survey data (this is prevented by insisting on email contact addresses to track completion of surveys by individuals more than once), and those invested less time and energy when completing the survey, resulting in distortions, deliberate or otherwise.

The relationship between Life Purpose and Life Satisfaction requires further study and research. This study has attempted to look at these relationships with the added aspect of life's purpose, defined as the extent to which a person engages in purposeful activities that are personally valued. 
This study is the first to examine the relationship between character strengths, happiness orientations and their relationships with life satisfaction and life purpose using a Singapore sample comprising citizens and permanent residents. In the study of commonality of character strengths, as a fact of human nature, the four top character strengths; Zest, Gratitude, Hope, Curiosity and Capacity to Love are to be investigated specifically and in greater depth. Previous studies only involved a very small number of Singapore participants, most of which were schooled in psychology at the postgraduate level. The Chinese were well represented in this study compared with the other ethnic groups. The sample sizes for these groups are too small for more sophisticated analyses based on ethnicity. As mentioned, caution must be taken when interpreting the results based on ethnicity in this study. In addition, as mentioned earlier, it will be good in future research to have the LET and OHS translated into collectivist language to better reflect Asian values and their understanding of the importance of the relationship of self with society at large. This would enable a better study of Asian relationships between life purpose and happiness.

A shortened version of the VIA-IS, retaining its reliability and validity for the adult population would be helpful for use in future studies. Four studies (Brdar \& Kasdan, 2010; Macdonald, Bore, \& Munro, 2008; Peterson, Park, Pole, D’Andrea, \& Seligman, 2008; and Singh \& Choubisa, 2010) having factor-analyzed the VIA had shown evidence of a three, four or five factor model, but there is not enough evidence replicated in the same manner to offer any in-depth or consistent findings. More needs to be done to confirm the underlying factors for the 24 character strengths supposedly measured by the VIA-IS. This is necessary so that professionals and researchers can all agree on the few to be studied instead of the long list of 24 character strengths.

\section{Conclusion}

As with the Americans, the present Singapore sample finds similar top character strengths of Zest, Hope, Curiosity, Capacity to Love and Gratitude. Character strengths of Zest, Hope, Curiosity and Capacity to Love are more prominent across ethnic groups in the present study. Happiness orientation through pursuing a life of meaning is preferred by all in the present study. This finding adds to the growing literature that people around the world are more similar in terms of their desires, goals and aspirations. There are some ethnic and gender differences in character strengths affecting life purpose and life satisfaction. The more pertinent finding is that Life Purpose and character strengths of Capacity to Love and Gratitude are strong predictors of life satisfaction whereas Life of Meaning and Life of Engagement happiness orientations are not direct predictors of life satisfaction. Three 
character strengths (Kindness, Religiousness and Spirituality, and Prudence) contribute directly to the prediction of the Life of Meaning happiness orientation and three character strengths (Modesty, Creativity and Self-regulation) contribute directly to the prediction of the Life of Engagement happiness orientation. These five character strengths do not contribute to Life Purpose directly but through the mediated pathways of the Life of Meaning happiness orientation and the Life of Engagement happiness orientation accordingly. It suggests that, for people in Singapore, the attainment of life satisfaction will be through finding a sense of purpose in life and having a sense of love and gratitude in their lives. When exploring a sense of life purpose, people in Singapore seem to be inclined to pursue a meaningful and engaged life while valuing character strengths of being curious and persevering.

Despite small ethnic sample sizes and other limitations, this study can be considered as laying the groundwork for future studies measuring happiness and its components using more robust sampling strategies and greater participation from the major ethnic groups in Singapore. According to a Chinese saying, harmony breeds prosperity. This study can be viewed as contributing to the knowledge field of psychological theory for understanding the positive, creative, malleable and emotionally fulfilling aspects of human behaviour to augment what we know about understanding suffering, treating illness and repairing weakness for nurturing well-being in individuals and communities.

\section{References}

Baumeister, R. F., \& Vohs, K. D. (2002). The pursuit of meaningfulness in life. In C. R. Snyder and S. J. Lopez (Eds.), Handbook of positive psychology (pp. 608-618). London: Oxford University Press.

Bermant, G., Talwar, C., \& Rozin, P. (2011). To celebrate positive psychology and extend its horizons. In K. M. Sheldon, T. B. Kashdan, \& M. F. Steger, (Eds.), Designing positive psychology: Taking stock and moving forward (pp. 430-438). New York: Oxford University Press.

Biswas-Diener, R. (2006). From the equator to the North Pole: A study of character strengths. Journal of Happiness Studies, 7, 293-310.

Brdar, I., \& Kasdan, T. B. (2010). Character strengths and well-being in Croatia: An empirical investigation of structure and correlates. Journal of Research in Personality, 44, 151-154. doi:10.1016/j.jrp.2009.12.001

Compton, W.C. (2005). An introduction to positive psychology. Belmont: Wadsworth, Cengage Learning.

Diener, E. (1994). Assessing subjective well-being: Progress and opportunities. Social Indicators Research, 31(2), 103 - 157.

Diener, E., Emmons, R.A., Larsen, R. J., \& Griffin, S. (1985). The Satisfaction with Life Scale. Journal of Personality Assessment, 49, 71-75.

Diener, E., Oishi, S., \& Lucas, R.E. (2003). Personality, culture, and subjective wellbeing: Emotional and cognitive evaluations of life. Annual Review of Psychology, 54, 403-425.

Diener , E., \& Scollon, C. (2003, October). Subjective well-being is desirable but not 
the summum bonum. Paper presented at the University of Minnesota Interdisciplinary Workshop on well-being. Mineneapolis.

Duckworth, A. L., Steen, T.A., \& Seligman, M. E. P. (2005). Positive psychology in clinical practice. Annual Review of Clinical Psychology, 1, 629-651.

Helliwell, J. F. (2011). Institutions as enablers of wellbeing: The Singapore prison case study. International Journal of Wellbeing, 1(2), 255-265. doi:10.5502/ijw.v1i2.7

Kasser, T., \& Ryan, R. M. (1993). A dark side of the American dream: Correlates of financial success as a life aspiration. Journal of Personality \& Social Psychology, 65(2), 410-422.

Kraut, R., Olson, J., Banaji, M., Bruckman, A., Cohen, J., \& Couper, M. (2004). Psychological research online: Report of board of scientific affairs advisory group on the conduct of research on the Internet. American Psychologist, 59, 105-117. doi:10.1037/0003-066X.59.2.105

Linley, P. A., Malty, J., Wood, A. M., Joseph, S., Harrington, S., Peterson, C., Park, N., Seligman, M. E. P. (2007). Character strengths in the United Kingdom: The VIA inventory of strengths. Personality and Individual Differences, 43, 341-351. doi: 10.1016/j.paid.2006.12.004

MacDonald, C., Bore, M., \& Munro, D. (2008). Values in action scale and the Big 5: An empirical indication of structure. Journal of Research in Personality, 42, 787799.

Marsh, A., Smith, L., Piek, J. \& Saunders, B. (2003). The Purpose in Life Scale: Psychometric properties for social drinkers and drinkers in alcohol treatment. Educational and Psychological Measurement, 63(5), 859 - 871.

Park, N., Park, M. \& Peterson, C. (2010). When is the search for meaning related to life satisfaction. Applied Psychology: Health and Well-Being, 2(1), 1-13.

Park, N., \& Peterson, C. (2009).Character strengths: Research and practice. Journal of College \& Character, 10 (4), 1-10.

Park, N., Peterson, C., \& Ruch, W. (2009). Orientations to happiness and life satisfaction in twenty-seven nations. Journal of Positive Psychology, 4(4), 273279.

Park, N., Peterson, C., \& Seligman, M. E. P. (2006). Character strengths in fifty-four nations and the fifty US states. Journal of Positive Psychology, 1(3), 118-129.

Park, N., Peterson, C., \& Seligman, M. E. P. (2004). Strengths of character and wellbeing. Journal of Social and Clinical Psychology, 23(5), 603-619.

Peterson, C., Park, N., Pole, N., D’Andrea, W., \& Seligman, M. E. P. (2008). Strengths of character and posttraumatic growth. Journal of Traumatic Stress, 21(2), 214217. doi: $10.1002 /$ jts. 20332

Peterson, C., Park, N. \& Seligman, M.E. P. (2005). Orientations to happiness and life satisfaction: The full life versus the empty life. Journal of Happiness Studies, 6(1), 25-41. doi: 10.1007/s10902-004-1278-Z

Peterson, C., Park, N., \& Seligman, M. E. P. (2006).Greater strengths of character and recovery from illness. Journal of Positive Psychology, 1(1), 17-26.

Peterson, C., \& Seligman, M. E. P. (2004). Character strengths and virtues: A handbook and classification. New York: Oxford University Press.

Peterson, C., Ruch, W., Beermann, U., Park, N., \& Seligman, M. E. P. (2007). Strengths of character, orientations to happiness and life satisfaction. Journal of Positive Psychology, 2(3), 149-156.

Proctor, C., Maltby, J., \& Linley, P. A. (2010). Strengths use as a predictor of wellbeing and health-related quality of life. Journal of Happiness Studies, 12(1), 153-169. doi:10.1007/s10902-009-9181-2 
Scheier, M. F., Wrosch, C., Baum, A., Cohen, S., Martire, L.M., Matthews, K.A., ...Zdaniuk, B. (2006). The Life Engagement Test: Assessing purpose in life. Journal of Behavioral Medicine, 29(3), 291-298.

Seligman, M.E. P. (2011). Flourish: A visionary understanding of happiness and wellbeing. New York: Free Press.

Seligman, M. E. P. (2002). Authentic happiness: Using the new positive psychology to realize your potential for lasting fulfilment. New York: Free Press.

Seligman, M. E. P., \& Csikszentmihalyi, M. (2000). Positive Psychology: An introduction. American Psychologist, 55(1), 5-14.

Seligman, M. E. P., Steen, T. A., Park, N., \& Peterson, C. (2005). Positive psychology progress: Empirical validation of interventions. American Psychologist, 60(5), 410-421.

Seligman, M. E. P. \& Peterson, C. (2003). Positive clinical psychology. In L. G. Aspinwall \& U. M. Staudinger (Eds.), A psychology of human strengths: Fundamental questions and future directions for a positive psychology (pp. 305-317). Washington, DC: American Psychological Association.

Sirgy, M. J. (1998). Materialism and quality of life. Social Indicators Research, 43(3), 227-260.

Singh, K., \& Choubisa, R. (2010). Empirical validation of values in Action-Inventory of Strengths (VIA-Is) in Indian context. Psychological Studies, 55(2), 151-158. doi: 10.1007/s12646-010-0015-4

Steger, M. F., Frazier, P., Oishi, S., \& Kaler, M. (2006). The meaning in life questionnaire: Assessing the presence of and search for meaning in life. Journal of Counseling Psychology, 53 (1), 80-93.

Suh, E. M., \& Oishi, S. (2002). Subjective Well-Being Across Cultures. Online Readings in Psychology and Culture, Unit 10. Retrieved from http://scholarworks.gvsu.edu/orpc/vol10/iss 1/1

Tafarodi, R. W., Bonn, G., Liang, H., Takai,J., Moriizumi, S., Belhekar, V., \& Padhye, A. (2011). What makes for a good life? A four-nation study. Journal of Happiness Studies, doi: 10.1007/s10902-011-9290-6

Tambyah, S. K., Tan, S. J., \& Kau, A. K. (2010). The wellbeing of Singaporeans: Values, lifestyles, satisfaction and quality of life. Singapore: World Scientific Publishing Co. Pte Ltd.

Tamir, M., \& Gross, J. J. (2011). Beyond pleasure and pain? Emotion regulation and positive psychology. In K. M. Sheldon, T. B. Kashdan, \& M. F. Steger, (Eds.), Designing positive psychology: Taking stock and moving forward (pp. 89-100). New York: Oxford University Press.

Teng, S. (2011). Conflict and Harmony in Multi-Ethnic Societies. Retrieved from: http://libguides.nl.sg/conflictandharmony

Trach, C. \& Lyubomirsky, S. (2006). How do people pursue happiness? Relating personality, happiness-increasing strategies and well-being. Journal of Happiness Studies, 7(2), 183-225.

Vaingankar, J. A., Subramaniam, M., Chong, S. A., Abdin, E., Edelen, M.O., Picco, L., ...Sherbourne, C. (2011). The positive mental health instrument: development and validation of a culturally relevant scale in a multi-ethnic Asian population. Health and Quality of Life Outcomes, 9, 92-110. doi: 10.1186/1477-7525-9-92

Veenhoven, R. (2011). Greater happiness for a greater number: Is that possible? If so, how? In K. M. Sheldon, T. B. Kashdan, \& M. F. Steger, (Eds.), Designing positive psychology: Taking stock and moving forward (pp. 396-409). New York: Oxford University Press. 
Running Head: CHARACTER STRENGTHS IN SINGAPORE

Wrosch, C., Scheier, M. F., Miller, G. E., Schulz, R., \& Carver, C. S. (2003). Adaptive self-regulation of unattainable goals: Goal disengagement, goal re-engagement and subjective well-being. Personality and Social Psychology Bulletin, 29(12), 1494-1508. 
Demographic Information

First Name*

Last Name*

Age in Years (must be 18 years and above)*

Email Address*

Gender*

Nationality*

Ethnic Group*

*If Others, please specify. If not, please skip to the next question.

Occupation*

Education Level*

Marital Status*

\section{Happiness Orientation}

DIRECTIONS: Below are 18 statements that many people would find desirable, but we want you to answer only in terms of whether the statement describes how you actually live your life. Read each one and then using the Likert scale below and select your option in response. Please be open and honest in your responding.

1. Regardless of what I'm doing, time passes very quickly*

( ) Not Like Me At All

( ) A Little Like Me

( ) Somewhat Like Me

( ) Mostly Like Me

( ) Very Much Like Me

2. My life serves a higher purpose.*

3. Life is too short to postpone the pleasures it can provide*

4. I seek out situations that challenge my skills and abilities.*

5. In choosing what to do, I always take into account whether it will benefit other people.*

6 . Whether at work or play, I am usually "in a zone" and not conscious of myself.*

7. I am always very absorbed in what I do.*

8. I go out of my way to feel euphoric.*

9. In choosing what to do, I always take into account whether I can lose myself in it.*

10. I am rarely distracted by what is going on around me.*

11. I have a responsibility to make the world a better place.*

12. My life has a lasting meaning.*

13. In choosing what to do, I always take into account whether it will be pleasurable.*

14. What I do matters to society.*

15. I agree with this statement: "Life is short-eat dessert first."*

16. I love to do things that excite my senses.*

17. I have spent a lot of time thinking about what life means and how I fit into its big picture.*

18. For me, the good life is the pleasurable life.*

Satisfaction With Life

DIRECTIONS: Below are five statements with which you may agree or disagree. Read each one and then using the scale below and select your option in response. Please be open and honest in your responses.

1. In most ways, my life is close to my ideal.*

( ) Strongly Disagree

( ) Disagree

( ) Slightly Disagree

( ) Neither Agree Nor Disagree

( ) Slightly Agree

( ) Agree

( ) Strongly Agree

2. The conditions of my life are excellent.*

3. I am completely satisfied with my life.*

4. So far I have gotten the most important things I want in life.*

5. If I could live my life over, I would change nothing.*

Life Engagement

DIRECTIONS: Please the following 6 questions about yourself by indicating the extent of your agreement. Be as honest as you can throughout, and try not to let your answer to one question influence your answers to other questions. There are no right or wrong answers.

1. There is not enough purpose in my life.*

( ) Strongly Disagree

( ) Disagree

( ) Neutral

( ) Agree

( ) Strongly Agree 


\section{Running Head: CHARACTER STRENGTHS IN SINGAPORE}

2. To me, the things I do are all worthwhile.*

3. Most of what I do seems trivial and unimportant to me.*

4. I value my activities a lot.*

5. I don't care very much about the things I do.*

6 . I have lots of reasons for living.*

Character Strengths

Please choose one option in response to each statement. The questions reflect statements that many people would find desirable, but we want you to answer only in terms of whether the statement describes what you are like. Please be open and honest.

[Note that for the journal, the subscale (e.g., Curiosity) is placed in parentheses at the end of each statement. In the study, the participant does not see this.]

1. I find the world a very interesting place. (Curiosity)

( ) Very Much Like Me

( ) Like Me

( ) Neutral

( ) Unlike Me

( ) Very Much Unlike Me

2. I always go out of my way to attend educational events. (Learning)

3. I always identify the reasons for my actions. (Judgment \& Open-mindedness)

4. Being able to come up with new and different ideas is one of my strong points. (Creativity)

5 . I am very aware of my surroundings. (Social Intelligence)

6. I always have a broad outlook on what is going on. (Perspective)

7. I have taken frequent stands in the face of strong opposition. (Bravery)

8. I never quit a task before it is done. (Perseverance)

9. I always keep my promises. (Honesty)

10. I am never too busy to help a friend. (Kindness)

11. I am always willing to take risks to establish a relationship. (Capacity to Love)

12. I never miss group meetings or team practices. (Teamwork)

13. I always admit when I am wrong. (Fairness)

14. In a group, I try to make sure everyone feels included. (Leadership)

15. I have no trouble eating healthy foods. (Self-Regulation)

16. I have never deliberately hurt anyone. (Prudence)

17. It is important to me that I live in a world of beauty. (Appreciation of Beauty and Excellence)

18. I always express my thanks to people who care about me. (Gratitude)

19. I always look on the bright side. (Hope)

20. I am a spiritual person. (Religiousness \& Spirituality)

21. I am always humble about the good things that have happened to me. (Modesty)

22. Whenever my friends are in a gloomy mood, I try to tease them out of it. (Humor)

23. I want to fully participate in life, not just view it from the sidelines. (Zest)

24. I always let bygones be bygones. (Forgiveness)

25. I am never bored. (Curiosity)

26. I love to learn new things. (Learning)

27. I always examine both sides of an issue. (Judgment \& Open-mindedness)

28. When someone tells me how to do something, I automatically think of alternative ways to get the same thing done. (Creativity)

29. I know how to handle myself in different social situations. (Social Intelligence)

30. Regardless of what is happening, I keep in mind what is most important. (Perspective)

31. I have overcome an emotional problem by facing it head on. (Bravery)

32. I always finish what I start. (Perseverance)

33. My friends tell me that I know how to keep things real. (Honesty)

34. I really enjoy doing small favors for friends. (Kindness)

35. There are people in my life who care as much about my feelings and well-being as they do about their own. (Capacity to Love)

36. I really enjoy being a part of a group. (Teamwork)

37. Being able to compromise is an important part of who I am. (Fairness)

38. As a leader, I treat everyone equally well regardless of his or her experience. (Leadership)

39. Even when candy or cookies are under my nose, I never overeat. (Self-Regulation)

40. Better safe than sorry is one of my favorite mottoes. (Prudence)

41. The goodness of other people almost brings tears to my eyes. (Appreciation of Beauty and Excellence)

42. I get chills when I hear about acts of great generosity. (Gratitude)

43. I can always find the positive in what seems negative to others. (Hope)

44. I practice my religion. (Religiousness \& Spirituality)

45. I do not like to stand out in a crowd. (Modesty)

46. Most people would say I am fun to be with. (Humor)

47. I never dread getting up in the morning. (Zest)

48. I rarely hold a grudge. (Forgiveness)

49. I am always busy with something interesting. (Curiosity)

50. I am thrilled when I learn something new. (Learning)

51. I make decisions only when I have all of the facts. (Judgment \& Open-mindedness)

52. I like to think of new ways to do things. (Creativity)

53. No matter what the situation, I am able to fit in. (Social Intelligence) 


\section{Running Head: CHARACTER STRENGTHS IN SINGAPORE}

54. My view of the world is an excellent one. (Perspective)

55. I never hesitate to publicly express an unpopular opinion. (Bravery)

56. I am a goal-oriented person. (Perseverance)

57. I believe honesty is the basis for trust. (Honesty)

58. I go out of my way to cheer up people who appear down. (Kindness)

59. There are people who accept my shortcomings. (Capacity to Love)

60. I am an extremely loyal person. (Teamwork)

61. I treat all people equally regardless of who they might be. (Fairness)

62. One of my strengths is helping a group of people work well together even when they have their differences. (Leadership)

63. I am a highly disciplined person. (Self-Regulation)

64. I always think before I speak. (Prudence)

65. I experience deep emotions when I see beautiful things. (Appreciation of Beauty and Excellence)

66. At least once a day, I stop and count my blessings. (Gratitude)

67. Despite challenges, I always remain hopeful about the future. (Hope)

68. My faith never deserts me during hard times. (Religiousness \& Spirituality)

69. I do not act as if I am a special person. (Modesty)

70. I welcome the opportunity to brighten someone else's day with laughter. (Humor)

71. I never approach things halfheartedly. (Zest)

72. I never seek vengeance. (Forgiveness)

73. I am always curious about the world. (Curiosity)

74. Every day, I look forward to the opportunity to learn and grow. (Learning)

75. I value my ability to think critically. (Judgment \& Open-mindedness)

76. I pride myself on being original. (Creativity)

77. I have the ability to make other people feel interesting. (Social Intelligence)

78. I have never steered a friend wrong by giving bad advice. (Perspective)

79. I must stand up for what I believe even if there are negative results. (Bravery)

80. I finish things despite obstacles in the way. (Perseverance)

81. I tell the truth even if it hurts. (Honesty)

82. I love to make other people happy. (Kindness)

83. I am the most important person in someone else's life. (Capacity to Love)

84. I work at my very best when I am a group member. (Teamwork)

85. Everyone's rights are equally important to me. (Fairness)

86. I am very good at planning group activities. (Leadership)

87. I control my emotions. (Self-Regulation)

88. My friends believe that I make smart choices about what I say and do. (Prudence)

89. I see beauty that other people pass by without noticing. (Appreciation of Beauty and Excellence)

90. If I receive a gift, I always let the person who gave it know I appreciated it. (Gratitude)

91. I have a clear picture in my mind about what I want to happen in the future. (Hope)

92. My life has a strong purpose. (Religiousness \& Spirituality)

93. I never brag about my accomplishments. (Modesty)

94. I try to have fun in all kinds of situations. (Humor)

95. I love what I do. (Zest)

96. I always allow others to leave their mistakes in the past and make a fresh start. (Forgiveness)

97. I am excited by many different activities. (Curiosity)

98. I am a true life-long learner. (Learning)

99. My friends value my objectivity. (Judgment \& Open-mindedness)

100. I am always coming up with new ways to do things. (Creativity)

101. I always know what makes someone tick. (Social Intelligence)

102. People describe me as "wise beyond my years." (Perspective)

103. I call for action while others talk. (Bravery)

104. I am a hard worker. (Perseverance)

105. My promises can be trusted. (Honesty)

106. I have voluntarily helped a neighbor in the last month. (Kindness)

107. My family and close friends cannot do anything that would make me stop loving them. (Capacity to Love)

108. I never bad-mouth my group to outsiders. (Teamwork)

109. I give everyone a chance. (Fairness)

110. To be an effective leader, I treat everyone the same. (Leadership)

111. I never want things that are bad for me in the long run, even if they make me feel good in the short run. (Self-Regulation)

112. I always avoid activities that are physically dangerous. (Prudence)

113. I have often been left speechless by the beauty depicted in a movie. (Appreciation of Beauty and Excellence)

114. I am an extremely grateful person. (Gratitude)

115. If I get a bad grade or evaluation, I focus on the next opportunity, and plan to do better. (Hope)

116. In the last 24 hours, I have spent 30 minutes in prayer, meditation or contemplation. (Religiousness \& Spirituality)

117. I am proud that I am an ordinary person. (Modesty)

118. I try to add some humor to whatever I do. (Humor)

119. I look forward to each new day. (Zest)

120. I believe it is best to forgive and forget. (Forgiveness)

121. I have many interests. (Curiosity)

122. I always go out of my way to visit museums. (Learning)

123. When the topic calls for it, I can be a highly rational thinker. (Judgment \& Open-mindedness)

124. My friends say that I have lots of new and different ideas. (Creativity)

125. I always get along well with people I have just met. (Social Intelligence) 
126. I am always able to look at things and see the big picture. (Perspective)

127. I always stand up for my beliefs. (Bravery)

128. I do not give up. (Perseverance)

129. I am true to my own values. (Honesty)

130. I always call my friends when they are sick. (Kindness)

131. I always feel the presence of love in my life. (Capacity to Love)

132. It is important for me to maintain harmony within my group. (Teamwork)

133. I am strongly committed to principles of justice and equality. (Fairness)

134. I believe that our human nature brings us together to work for common goals. (Leadership)

135. I can always stay on a diet. (Self-Regulation)

136. I think through the consequences every time before I act. (Prudence)

137. I am always aware of the natural beauty in the environment. (Appreciation of Beauty and Excellence)

138. I go to extremes to acknowledge people who are good to me. (Gratitude)

139. I have a plan for what I want to be doing five years from now. (Hope)

140. My faith makes me who I am. (Religiousness \& Spirituality)

141. I prefer to let other people talk about themselves. (Modesty)

142. I never allow a gloomy situation to take away my sense of humor. (Humor)

143. I have lots of energy. (Zest)

144. I am always willing to give someone a chance to make amends. (Forgiveness)

145. I can find something of interest in any situation. (Curiosity)

146. I read all of the time. (Learning)

147. Thinking things through is part of who I am. (Judgment \& Open-mindedness)

148. I am an original thinker. (Creativity)

149. I am good at sensing what other people are feeling. (Social Intelligence)

150. I have a mature view on life. (Perspective)

151. I always face my fears. (Bravery)

152. I never get sidetracked when I work. (Perseverance)

153. I take pride in not exaggerating who or what I am. (Honesty)

154. I am as excited about the good fortune of others as I am about my own. (Kindness)

155. I can express love to someone else. (Capacity to Love)

156. Without exception, I support my teammates or fellow group members. (Teamwork)

157. I refuse to take credit for work I have not done. (Fairness)

158. My friends always tell me I am a strong but fair leader. (Leadership)

159. I can always say "enough is enough." (Self-Regulation)

160. I always keep straight right from wrong. (Prudence)

161. I greatly appreciate all forms of art. (Appreciation of Beauty and Excellence)

162. I feel thankful for what I have received in life. (Gratitude)

163. I know that I will succeed with the goals I set for myself. (Hope)

164. I believe that each person has a purpose in life. (Religiousness \& Spirituality)

165. I rarely call attention to myself. (Modesty)

166. I have a great sense of humor. (Humor)

167. I cannot wait to get started on a project. (Zest)

168. I rarely try to get even. (Forgiveness)

169. It is very easy for me to entertain myself. (Curiosity)

170. If I want to know something, I immediately go to the library or the Internet and look it up. (Learning)

171. I always weigh the pro's and con's. (Judgment \& Open-mindedness)

172. My imagination stretches beyond that of my friends. (Creativity)

173. I am aware of my own feelings and motives. (Social Intelligence)

174. Others come to me for advice. (Perspective)

175. I have overcome pain and disappointment. (Bravery)

176. I stick with whatever I decide to do. (Perseverance)

177. I would rather die than be phony. (Honesty)

178. I enjoy being kind to others. (Kindness)

179. I can accept love from others. (Capacity to Love)

180. Even if I disagree with them, I always respect the leaders of my group. (Teamwork)

181. Even if I do not like someone, I treat him or her fairly. (Fairness)

182. As a leader, I try to make all group members happy. (Leadership)

183. Without exception, I do my tasks at work or school or home by the time they are due. (Self-Regulation)

184. I am a very careful person. (Prudence)

185. I am in awe of simple things in life that others might take for granted. (Appreciation of Beauty and Excellence)

186. When I look at my life, I find many things to be grateful for. (Gratitude)

187. I am confident that my way of doing things will work out for the best. (Hope)

188. I believe in a universal power, a god. (Religiousness \& Spirituality)

189. I have been told that modesty is one of my most notable characteristics. (Modesty)

190. I find satisfaction in making others smile or laugh. (Humor)

191. I can hardly wait to see what life has in store for me in the weeks and years ahead. (Zest)

192. I am usually willing to give someone another chance. (Forgiveness)

193. I think my life is extremely interesting. (Curiosity)

194. I read a huge variety of books. (Learning)

195. I try to have good reasons for my important decisions. (Judgment \& Open-mindedness)

196. In the last month I have found an original solution to a problem in my life. (Creativity)

197. I always know what to say to make people feel good. (Social Intelligence) 


\section{Running Head: CHARACTER STRENGTHS IN SINGAPORE}

198. I may not say it to others, but I consider myself to be a wise person. (Perspective)

199. I always speak up in protest when I hear someone say mean things. (Bravery)

200. When I make plans, I am certain to make them work. (Perseverance)

201. My friends always tell me I am down to earth. (Honesty)

202. I am thrilled when I can let others share the spotlight. (Kindness)

203. I have a neighbor or someone at work or school that I really care about as a person. (Capacity to Love)

204. It is important to me to respect decisions made by my group. (Teamwork)

205. I believe that everyone should have a say. (Fairness)

206. As a leader, I believe that everyone in the group should have a say in what the group does. (Leadership)

207. For me, practice is as important as performance. (Self-Regulation)

208. I always make careful choices. (Prudence)

209. I often have a craving to experience great art, such as music, drama, or paintings. (Appreciation of Beauty and Excellence)

210. I feel a profound sense of appreciation every day. (Gratitude)

211. If I feel down, I always think about what is good in my life. (Hope)

212. My beliefs make my life important. (Religiousness \& Spirituality)

213. No one would ever describe me as arrogant. (Modesty)

214. I believe life is more of a playground than a battlefield. (Humor)

215. I awaken with a sense of excitement about the day's possibilities. (Zest)

216. I do not want to see anyone suffer, even my worst enemy. (Forgiveness)

217. I really enjoy hearing about other countries and cultures. (Curiosity)

218. I love to read nonfiction books for fun. (Learning)

219. My friends value my good judgment. (Judgment \& Open-mindedness)

220. I have a powerful urge to do something original during this next year. (Creativity)

221. It is rare that someone can take advantage of me. (Social Intelligence)

222. Others consider me to be a wise person. (Perspective)

223. I am a brave person. (Bravery)

224. When I get what I want, it is because I worked hard for it. (Perseverance)

225. Others trust me to keep their secrets. (Honesty)

226. I always listen to people talk about their problems. (Kindness)

227. I easily share feelings with others. (Capacity to Love)

228. I gladly sacrifice my self-interest for the benefit of the group I am in. (Teamwork)

229. I believe that it is worth listening to everyone's opinions. (Fairness)

230. When I am in a position of authority, I never blame others for problems. (Leadership)

231. I exercise on a regular basis. (Self-Regulation)

232. I cannot imagine lying or cheating. (Prudence)

233. I have created something of beauty in the last year. (Appreciation of Beauty and Excellence)

234. I have been richly blessed in my life. (Gratitude)

235. I expect the best. (Hope)

236. I have a calling in my life. (Religiousness \& Spirituality)

237. People are drawn to me because I am humble. (Modesty)

238. I am known for my good sense of humor. (Humor)

239. People describe me as full of zest. (Zest)

240. I try to respond with understanding when someone treats me badly. (Forgiveness)

Thank You!

Thank you for taking our survey. Your response is very important to us. 